\title{
Men, Women, and Machines: How Trade Impacts Gender Inequality
}

\author{
Chinhui Juhn, \\ Gergely Ujhelyi ${ }^{b}$ \\ and Carolina Villegas-Sanchez ${ }^{\mathrm{c}}$
}

January 2013

\begin{abstract}
This paper studies the effect of trade liberalization on an under-explored aspect of wage inequality - gender inequality. We consider a model where firms differ in their productivity and workers are differentiated by skill as well as gender. A reduction in tariffs induces more productive firms to modernize their technology and enter the export market. New technologies involve computerized production processes and lower the need for physically demanding skills. As a result, the relative wage and employment of women improves in blue-collar tasks, but not in white-collar tasks. We test our model using a panel of establishment level data from Mexico exploiting tariff reductions associated with the North American Free Trade Agreement (NAFTA). Consistent with our theory we find that tariff reductions caused new firms to enter the export market, update their technology and replace male blue-collar workers with female blue-collar workers.
\end{abstract}

JEL: D3,F15,J16 .

Keywords: trade, gender, inequality.

\footnotetext{
${ }^{a}$ Corresponding author. University of Houston and NBER, Department of Economics, University of Houston, Houston, TX 77204-5882, (Tel) 713-743-3823, (Email) cjuhn@uh.edu

${ }^{\mathrm{b}}$ University of Houston, Department of Economics, University of Houston, Houston, TX 77204-5882, (Tel) 713743-3815, (Email) gujhelyi@uh.edu

${ }^{\mathrm{c}}$ ESADE-Universitat Ramon Llul, Department of Economics, E-08034 Barcelona, Spain, (Tel) +34-932-806-162, (Email) carolina.villegas@esade.edu
} 


\section{Introduction}

A large literature now examines the impact of trade liberalization on wage inequality in developing economies and the findings have been surprising. Contrary to the Heckscher-Ohlin model of trade which predicts that wage inequality should fall in developing countries which are abundant in low-skilled labor, most researchers have found that trade liberalization actually increased wage inequality in these countries. ${ }^{1}$ Moreover, empirical evidence suggests that trade liberalization is not so much associated with labor reallocation across sectors, but rather with skill-upgrading within industries and firms - a phenomenon reminiscent of the skill-biased technical change (SBTC) theory put forward in the U.S. ${ }^{2}$

In this paper, we build on the basic framework of the new trade models of Melitz (2003), Bustos (011a), Bustos (011b) and their predecessors to consider an under-explored aspect of trade liberalization - its impact on gender inequality in the labor market. Given that many developing countries have already adopted or are now in the process of adopting trade liberalization policies, an important question is whether this will move them closer to, or further from, the goal of gender equality, one of the eight stated goals in the U.N. Millennium Development Goals Report (UN, 2009). Aside from equity concerns, the effect of liberalization policies on gender outcomes may also be of interest from a long-run growth perspective since there is now growing evidence that empowering women promotes education and better children's outcomes (Thomas (1990), Duflo (2003), Qian (2008)). Thus, in our view, the impact of trade openness on gender inequality is an important question which deserves equal attention to that given to skill premia.

In our model, heterogenous firms choose between old and new technologies that require different amounts of white and blue-collar tasks. White and blue collar tasks can be performed by male or female workers. Reminiscent of Autor et al. (2003) in which computers replace the need for routine physical tasks, the new technology in our model replaces the need for physically demanding skills,

\footnotetext{
${ }^{1}$ Some earlier studies in the Mexican context include Cragg and Epelbaum (1996), Revenga (1997), Hanson and Harrison (1999), Behrman et al. (2000), Feliciano (2001), Robertson (2004). See Goldberg and Pavcnik (2007) for a review.

${ }^{2}$ The substantial skill upgrading within industries, for example, is documented in Revenga (1997), Hanson and Harrison (1999), Pavcnik (2003), Attanasio et al. (2004), Topalova and Khandelwal (2004), among others.
} 
"brawn." 3 Thus, relative to the old technology, women are more productive in blue-collar jobs in the new technology. By lowering the cost of entering foreign markets, trade liberalization causes some firms to start exporting and adopt the modern technology. This improves women's labor market outcomes in the blue-collar tasks, while leaving them unchanged in the white-collar tasks.

We test our model using establishment level data from Mexico, exploiting tariff reductions associated with the North American Free Trade Agreement (NAFTA). Consistent with the previous literature and the predictions of our model, we find that tariff reductions increased exports through the entry of new firms into the export sector. We find evidence that these newly exporting firms updated their machinery and equipment, not only relative to non-exporting firms but also relative to existing exporters. Moreover, investment was especially pronounced in the new, computerized equipment category imported from developed countries. As predicted by our model, we find that tariff reductions improved female labor outcomes through this channel. Trade liberalization increased the ratio of female blue-collar workers to male blue-collar workers as well as the relative wage of female blue-collar workers. By contrast, we find little evidence of increasing female shares in white-collar occupations, where the relative importance of physically demanding skills is unlikely to have changed.

In terms of skill-upgrading (measured as the ratio of white-collar to blue-collar workers), we find mixed results. We find little evidence of skill-upgrading in newly exporting firms in terms of employment but we do find larger increase in white-collar wages, both in absolute terms and relative to blue-collar wages. These results are consistent with the idea that labor inputs are differentiated along multiple dimensions: gender-specific skills as well as the more traditional occupation-specific skills. We provide evidence that other mechanisms, including import market competition or the different attitudes towards women among foreign firms are unlikely to explain our findings.

In studying the effect of trade liberalization on gender inequality, our paper brings together two distinct literatures: a trade literature on the effects of trade liberalization in developing countries, and a labor literature on skill-biased technological change. The first, more recent literature has studied the effect of trade liberalization on heterogenous firms, finding evidence for technology and

\footnotetext{
${ }^{3}$ Empirical evidence in Weinberg (2000) and Rendall (2010) on the process of technological change in the US also supports this assumption.
} 
quality upgrading as well as wage effects. Building on the insights of endogenous technological change in Acemoglu (2003), Bustos (011b) builds a model where firms that differ in productivity choose technology as well as export status. Lower trade costs encourage the most productive firms to incur a fixed cost to upgrade technology which uses more skilled labor. Using a panel of Argentinean manufacturing firms in the context of a regional free trade agreement, MERCOSUR, Bustos finds that trade liberalization led to increases in spending on technology and hiring of more skilled workers. Verhoogen (2008) uses a similar set-up but uses exchange rate shocks, rather than tariff reductions, as source of variation. In his model, heterogeneous firms produce goods of different quality and only the most productive firms producing the highest quality goods export to rich Northern neighbors. An exchange rate shock lowers the cost of producing quality and lowers the cut-off level for export status. Using a panel data set of Mexican manufacturing plants, he finds that the 1994-1995 peso devaluation increased exports and wages particularly at those plants with higher initial productivity. Csillag and Koren (2011) study a period of trade liberalization in Hungary, and show that employees working with machinery imported from developed countries earn a wage premium. They argue that such machinery represents technology upgrading, which is consistent with the interpretation of our findings. ${ }^{4}$

The second literature is a labor literature on skill-biased technological change that has described the implications of technology upgrading for gender inequality. This literature has primarily focused on the evolution of wage inequality between men and women in the US (e.g., Blau and Kahn (1997), Weinberg (2000), Autor et al. (2003), Rendall (2010)). We take from this literature the idea that technological change, in particular the introduction of computerized production processes, has lowered the need for physically demanding skills and has therefore favored women in certain occupations.

While the link between trade liberalization and demand for skilled workers has been widely and

\footnotetext{
${ }^{4}$ Different approaches have been taken to model how firm-level heterogeneity translates into wage inequality among workers. Departing from the assumption of perfect labor markets, Helpman et al. (2010) and Helpman et al. (2011) introduce search frictions where more productive firms search more intensively for quality workers and pay higher wages. Similarly, Amiti and Davis (2012) develop a model of fair wages in which more productive firms share profits and pay higher wages to workers. Trade and the entry of these productive firms into the export sector increases their revenue relative to non-exporting firms, thereby increasing wage dispersion across firms. Frias et al. (2009) show that labor market imperfections are empirically important in explaining the higher wages paid by exporting firms.
} 
rigorously examined with firm and industry level data, there is relatively little work exploring labor market outcomes of men and women. Most previous papers use household surveys to examine trends in the gender wage gap and are different from the approach taken here. In one of the earliest studies to employ firm-level data to study gender outcomes, Ozler (2000) finds that female employment share is positively related to export share of output among manufacturing plants in Turkey. The study is based on a single cross section and does not discuss the possible channels leading to this empirical finding. Ederington et al. (2010) use firm level data and find that Colombian tariff reforms increased relative employment of blue-collar women, an empirical finding they interpret as being due to reductions in discrimination. Aguayo et al. (2013) use household and firm level data and find tariff changes accompanying NAFTA increased demand for female labor within and between industries. Relative to this previous paper, we offer a more in-depth analysis of the mechanisms underlying the within-industry increase in female employment and wage bill share. ${ }^{5}$

More broadly, our paper contributes to the literature on the determinants of gender roles during the process of economic development (see, e.g., Alesina et al. (2011) or the survey by Duflo (2012)). Our results suggest that the opening up of trade may have important consequences for the status of women in society.

This paper is organized as follows. Section 2 summarizes the tariff reductions that accompanied signing of NAFTA in 1994 and describes the basic trends in relative wages and employment of women in Mexico over the 1990s. Section 3 outlines the model which links trade liberalization and the demand for female labor. Section 4 describes the data. Section 5 presents the main empirical results. Section 6 concludes.

\section{Background}

\subsection{Trade Liberalization under NAFTA}

Mexico implemented unilateral tariff reductions in the 1980s to join the GATT in 1986. By 1987, the highest tariff was reduced to $20 \%$ and the tariff structure was simplified to include only 5 different rates: $0 \%, 5 \%, 10 \%, 15 \%, 20 \%$. Starting in 1990, Mexico's opening strategy switched to

\footnotetext{
${ }^{5}$ See Juhn et al. (2013) for a summary of some of our results.
} 
pursuing bilateral free trade agreements, with the most important being the North American Free Trade Agreement (NAFTA) with U.S. and Canada which took effect in 1994. NAFTA reduced tariff rates with the U.S. from a maximum of $20 \%$ to zero in 15 years and many of the reductions to zero took immediate effect (Zabludovsky (2005)). Table 1 reports information on Mexican tariffs imposed on imports from NAFTA countries and US NAFTA tariffs. ${ }^{6}$ The upper panel shows US tariff levels in 1991 before NAFTA and the change from 1991-2000. Similarly, the lower panel shows Mexican import tariffs in 1991 as well as the change in tariffs from 1991-2000. As shown in Table 1, on average, tariffs applied by US (export tariffs) fell approximately 5 percentage points and there is considerable variation in the size of the declines across industries. Meanwhile, Mexican tariffs imposed on imports from NAFTA countries (import tariffs) decreased on average by 13 percentage points. Since more than $80 \%$ of the trade occurs with the U.S., we would expect a priori that the decline in tariffs would lead to large increases in trade flows. Figure 1 shows the trends in exports and imports as fractions of GDP. The figure shows that while the unilateral tariff reductions had some impact in the 1980s, trade flows accelerated in the 1990s, after the bilateral agreement with the major trading partner was reached. Interestingly, trade flows appear to have stagnated again in the 2000s most likely due to a recession in the U.S. and China's entry into the WTO.

\subsection{Trends in Women's Relative Wage and Employment Share}

While the focus of this paper is to study the impact of trade on production within the firm, it is nevertheless useful to start with an overview of the aggregate change in female wages and employment over this period. Aguayo et al. (2013) use household surveys to examine economywide changes. They conclude that women's relative wage increased slightly (see Figure 2) even as their relative employment rates increased, suggesting that demand for female labor in the economy as a whole increased. ${ }^{7}$ They find that a significant fraction (40 percent) of the increase in total wage

\footnotetext{
${ }^{6}$ We thank Leonardo Iacovone for providing us with the tariff data. Tariff data was available originally at the 8digit Harmonized System (HS) classification and was matched to the Mexican CMAP class classification as explained in Iacovone and Javorcik (2010).

${ }^{7}$ The figure is reproduced from Aguayo et al. (2013), and is based on Household Income and Expenditure Surveys (ENIGH) and the 1990 and 2000 Mexican Population Census. The wage sample consists of men and women who are 15-64 years old, who reported working full-time (30 hours or more), and who either did not have self-employment earnings or reported that they were not self-employed. We also winsorize the top and bottom 1 percent of observations
} 
bill share of women can be attributed to shifts in relative size of sectors (measured by employment or wage bill), a phenomenon which was spurred by the rapid decline of the agricultural sector. While labor allocation across sectors played a role, even a larger fraction of the increase in female wage bill share was due to within-industry shifts towards female labor, a phenomenon which we focus on here. Table 2 presents decompositions of the total change in female wage bill share into "between" and "within" industry shifts in employment and wage bill share. ${ }^{8}$ The top two panels of Table 2 are reproduced from Aguayo et al. (2013) and are based on household Census data. The top panel includes all sectors while the middle panel examines the tradeable sector (agriculture and manufacturing) which is directly impacted by tariffs. The bottom panel shows the results for our balanced panel of 938 firms. In all cases, the "within" industry shift towards female labor accounts for a large portion of the total change. Below, we investigate the link between trade liberalization and this type of within-industry and within-firm shifts towards female labor.

\subsection{Trade Liberalization and Gender}

Why would trade liberalization have a differential impact on female labor within industries and firms? One possible channel is through the reduction of discrimination brought about by foreign competition. In his seminal work, Becker (1957) hypothesized that employers who are prejudiced against a particular group will be disadvantaged and driven out of business in the long run by forces of competition. Testing this theory, Black and Brainerd (2004) compares across U.S. industries which were more and less impacted by trade. They find that industries which were subject to more competition through trade liberalization experienced greater reductions in the gender wage gap. A recent paper by Ederington et al. (2010) finds similar results for employment. Using the Colombian trade liberalization episode over the period 1985-1991 as the source of variation, they find that plants operating in industries subject to greater tariff reductions increased the hiring of female blue-collar workers relative to male blue-collar workers. The discrimination story begins with

\footnotetext{
by gender.

${ }^{8}$ The total change in female wage bill share is decomposed as in the following: $\Delta S_{t}=S_{t}-S_{\tau}=\sum_{j} \Delta s_{j t} E_{j \tau}+$ $\Sigma_{j} \Delta E_{j t} s_{j \tau}$, where $E_{j t}$ is the share of industry $j^{\prime} s$ wage bill in total wage bill at time $t, s_{j t}$ is the female wage bill as a share of total wage bill in industry $j$ at time $t$. The first expression after the equal sign refers to the "within" component while the latter refers to the "between" component.
} 
the assumption that men and women are equally productive in the production process. Another possibility, which we explore here, is that men and women embody different amounts and types of skills, and in particular, women have lower amounts of physical skill, "brawn," relative to men. The link between trade liberalization and technology upgrading is already well established (Bustos (011b)). In this paper we explore the notion that the new technology complements female labor by reducing the need for physical skills. Some of these ideas are explored in Weinberg (2000) who uses U.S. data and shows that female employment growth is positively related to computer-use across industries and occupations.

To get a sense of how employers view female and male workers, we examined questions on hiring preferences which were asked of employers in our balanced panel of firms. ${ }^{9}$ In the survey, employers were asked whether they had a preference for hiring males or females or whether they were indifferent between the two. Panel A of Table 3 summarizes the responses to this question by occupation category. The panel shows that there are large differences for male preference across occupation categories, with the most pronounced male preference being in blue-collar occupations such as "specialized workers" and "general workers." For white collar workers such as "managers" employers exhibit no particular preference for hiring male workers. While it is possible that employers discriminate differentially across occupation categories, we find the substantial variation in male preference across occupational categories as evidence that taste discrimination is not the major driving force. In a follow-up question employers are asked the reasons for their preferences and these answers are reported in Panel B of Table 3. For blue-collar occupations, "heavy work" is overwhelmingly the most common reason given for male preference. Table 3 gives credence to the notion that employers view men and women as distinct inputs with different amounts of skills, particularly when it comes to physical skills in blue-collar occupations.

\section{The Model}

The model below follows closely the extension of the Melitz (2003) model proposed by Bustos (2011a, 2011b). Bustos considers different production technologies and workers differentiated by skills along one dimension (low vs. high); we allow workers to be differentiated by both gender-

\footnotetext{
${ }^{9}$ See Section 4 for a full description of the ENESTyC survey and the data.
} 
specific and occupation-specific skills.

\subsection{Setup}

An economy has consumers with CES preferences buying a continuum of differentiated products.

Consumer utility is $\left[\int\left(q_{\omega}\right)^{\rho} d \omega\right]^{\frac{1}{\rho}}$ where $q_{\omega}$ is consumption of product variety $\omega$. Under prices $p_{\omega}$, demand for variety $\omega$ is $q_{\omega}=E P^{\sigma-1} p_{\omega}^{-\sigma}$, where $\sigma=\frac{1}{1-\rho}, E$ is total spending and $P$ is the price index.

Each product variety is produced by a single firm. Firms decide whether to enter the market at some fixed cost $f_{e}$. If they enter, they observe their productivity $\varphi$, a random draw from a Pareto distribution $G(\varphi)=1-\varphi^{-k}$ on $[1, \infty)$. Once productivity is realized, firms can exit. If they stay, they can choose between two technologies, 1 and 2. Technology 1 is a "traditional" technology involving relatively more physically demanding blue collar tasks (such as operating heavy machinery). Technology 2 is a "modern" technology that involves computerized production processes, and achieves higher total factor productivity. Labor is differentiated by both occupation (blue or white collar) and gender. White collar workers and female blue collar workers have relatively higher productivity under technology 2. This is based on empirical evidence in Bustos (011b), showing that exporting firms choose technologies that use more educated workers, and in Weinberg (2000), showing that modern computerized production technologies favor female workers. ${ }^{10}$

To capture these features, we assume that production involves a combination of blue collar $\left(Y_{b}\right)$ and white collar $\left(Y_{w}\right)$ intermediate inputs (or tasks) according to a Cobb Douglas production function

$$
Q_{t}\left(Y_{b}, Y_{w}\right)=A_{t}(\varphi) Y_{b}^{\alpha_{t}} Y_{w}^{1-\alpha_{t}}
$$

for each technology $t=1,2$. For simplicity, $A_{1}(\varphi)=\varphi$ and $A_{2}(\varphi)=\gamma \varphi$, where $\gamma>1$ to capture higher total factor productivity under the modern technology. We let $\alpha_{1}>\alpha_{2}$, capturing the importance of white collar tasks under the modern technology. We further let intermediate inputs

\footnotetext{
${ }^{10}$ See also Autor et al. (2003) and Rendall (2010).
} 
be produced using female $(f)$ and male $(m)$ labor with the appropriate skills (blue or white collar):

$$
\begin{aligned}
Y_{b}\left(L_{b f}, L_{b m}, t\right) & =\left(L_{b f}\right)^{\beta_{t}}\left(L_{b m}\right)^{1-\beta_{t}} \\
Y_{w}\left(L_{w f}, L_{w m}, t\right) & =\left(L_{w f}\right)^{\varpi_{t}}\left(L_{w m}\right)^{1-\varpi_{t}}
\end{aligned}
$$

for $t=1,2$. We assume $\beta_{1}<\beta_{2}$ to capture the higher productivity of female workers in the blue collar category with technology 2 . Technology 1 has a fixed cost $f_{1}$ and technology 2 a higher fixed cost $f_{2}>f_{1}$. Firms take factor prices $W=\left(W_{b f}, W_{b m}, W_{w f}, W_{w m}\right)$ and the price index $P$ of the consumption goods as given.

Firms that remain on the market also choose whether to export $(x)$ or serve only the domestic market $(d)$. The export market is characterized by the same demand structure as the domestic market. ${ }^{11}$ Exporting has a fixed cost $f_{x}$ and iceberg trade costs denoted $\tau$. Given the technology each firm maximizes its profit by choosing the price $p_{\omega}^{d}$ of its product on the domestic market (as well as a price $p_{\omega}^{x}$ if exporting) subject to consumer demand and the factor prices.

\subsection{Equilibrium}

Let $\delta$ be an indicator variable equal to 1 if a firm exports and 0 otherwise. Given the technology choice $(t=1,2)$ and the export decision, a firm's factor demand is $L_{j}^{t}(W, P, \varphi, \delta)$ for each type $j$ of the labor input $(j=b f, b m, w f, w m)$. These factor demands can be obtained using the firm's total cost function, which, for technology $t$ is

$$
T C_{t}(q, W, P, \varphi, \delta)=P f_{t}+\delta P f_{x}+\frac{q^{d}+\delta \tau q^{x}}{A_{t}(\varphi) \kappa_{t}} W_{b f}^{\alpha_{t} \beta_{t}} W_{b m}^{\alpha_{t}\left(1-\beta_{t}\right)} W_{w f}^{\left(1-\alpha_{t}\right) \varpi_{t}} W_{w m}^{\left(1-\alpha_{t}\right)\left(1-\varpi_{t}\right)},
$$

\footnotetext{
${ }^{11}$ One could allow domestic and foreign consumers to have different willingness to pay, as in Verhoogen (2008). Similarly, skill intensity in exporting firms could differ depending on the export market destination. Brambilla et al. (2012) find that firms that export to high-income destinations hire more skills and pay higher wages than firms that export to middle-income countries or that sell domestically. We assume away such destination-market effects to keep the model simple. In addition, our empirical investigation makes use of Mexican manufacturing data. US is the main destination market for Mexican exporters accounting for over 80 percent of total exports. Therefore, our dataset is ill-suited to study heterogenous effects across export market destinations.
} 
where $q^{d}$ and $q^{x}$ denote sales on the domestic and export markets, and $\kappa_{t}$ is a constant involving the parameters $\alpha_{t}, \beta_{t}$ and $\varpi_{t} .{ }^{12,13}$ Using Shepard's lemma, we can obtain the relative demand for female vs. male workers within each occupational category of a firm using technology $t$ as

$$
\begin{aligned}
\frac{L_{b f}^{t}}{L_{b m}^{t}} & =\frac{\partial T C_{t} / \partial W_{b f}}{\partial T C_{t} / \partial W_{b m}}=\frac{\beta_{t}}{1-\beta_{t}} \frac{W_{b m}}{W_{b f}} \\
\frac{L_{w f}^{t}}{L_{w m}^{t}} & =\frac{\partial T C_{t} / \partial W_{w f}}{\partial T C_{t} / \partial W_{w m}}=\frac{\varpi_{t}}{1-\varpi_{t}} \frac{W_{w m}}{W_{w f}} .
\end{aligned}
$$

Once the technology choice and the decision on exporting have been made, let $\pi_{t}(W, P, \varphi, \delta)$ denote a firm's maximized profit. Solving the firm's problem, this can be obtained as

$$
\pi_{t}(W, P, \varphi, \delta)=\left(1+\delta \tau^{1-\sigma}\right) r_{t}(W, P, \varphi) / \sigma-P f_{t}-\delta P f_{x}
$$

where $r_{t}(W, P, \varphi)=E(P \rho)^{\sigma-1}\left[W_{b f}^{\alpha_{t} \beta_{t}} W_{b m}^{\alpha_{t}\left(1-\beta_{t}\right)} W_{w f}^{\left(1-\alpha_{t}\right) \varpi_{t}} W_{w m}^{\left(1-\alpha_{t}\right)\left(1-\varpi_{t}\right)}\right]^{1-\sigma}\left(A_{t}(\varphi) \kappa_{t}\right)^{\sigma-1}$ is the revenue of a firm that does not export.

Comparing these profits, a firm with productivity $\varphi$ decides whether to stay on the market and whether to export. Specifically, there is a productivity cutoff $\varphi_{1}^{*}(W, P)$ above which firms stay in the market (i.e., serve at least the domestic market), a cutoff $\varphi_{x}^{*}(W, P)$ above which firms start exporting, and a cutoff $\varphi_{2}^{*}(W, P)$ above which they adopt technology 2. Given $W$ and $P$, these cutoffs determine total factor demand in the economy. For example, if $\varphi_{1}^{*}<\varphi_{x}^{*}<\varphi_{2}^{*}$, then total demand for type $j$ labor is

$$
L_{j}^{1}+L_{j}^{2}=\int_{\varphi_{1}^{*}}^{\varphi_{x}^{*}} L_{j}^{1}(W, P, \varphi, \delta=0) d G(\varphi)+\int_{\varphi_{x}^{*}}^{\varphi_{2}^{*}} L_{j}^{1}(W, P, \varphi, \delta=1) d G(\varphi)+\int_{\varphi_{2}^{*}}^{\infty} L_{j}^{2}(W, P, \varphi, \delta=1) d G(\varphi) .
$$

This can be easily computed using the Pareto distribution assumption and the factor demands from the firm's profit maximization problem. It will be convenient to work with ratios rather than

\footnotetext{
${ }^{12} \kappa_{t}=\left(\alpha_{t} \beta_{t}\right)^{\alpha_{t} \beta_{t}}\left(\alpha_{t}\left(1-\beta_{t}\right)\right)^{\alpha_{t}\left(1-\beta_{t}\right)}\left(\left(1-\alpha_{t}\right) \varpi_{t}\right)^{\left(1-\alpha_{t}\right) \varpi_{t}}\left(\left(1-\alpha_{t}\right)\left(1-\varpi_{t}\right)\right)^{\left(1-\alpha_{t}\right)\left(1-\varpi_{t}\right)}$

${ }^{13}$ This expression for the total costs assumes that prices are the same in the domestic and export markets, which will be true in equilibrium.
} 
levels, and we find

$$
\begin{aligned}
\frac{L_{b f}^{1}}{L_{b f}^{2}} & =\frac{\alpha_{1} \beta_{1}}{\alpha_{2} \beta_{2}} \frac{R_{1}}{R_{2}} \\
\frac{L_{b m}^{1}}{L_{b m}^{2}} & =\frac{\alpha_{1}\left(1-\beta_{1}\right)}{\alpha_{2}\left(1-\beta_{2}\right)} \frac{R_{1}}{R_{2}} \\
\frac{L_{w f}^{1}}{L_{w f}^{2}} & =\frac{\left(1-\alpha_{1}\right) \varpi_{1}}{\left(1-\alpha_{2}\right) \varpi_{2}} \frac{R_{1}}{R_{2}} \\
\frac{L_{w m}^{1}}{L_{w m}^{2}} & =\frac{\left(1-\alpha_{1}\right)\left(1-\varpi_{1}\right)}{\left(1-\alpha_{2}\right)\left(1-\varpi_{2}\right)} \frac{R_{1}}{R_{2}},
\end{aligned}
$$

where $R_{t}$ is the aggregate revenue of firms using technology $t$ (which is a function of the wages $W$, the productivity cutoffs and the price index $P$ ).

Equilibrium on the labor market requires aggregate demand for each type $j$ labor to equal its supply, assumed constant at $\bar{L}_{j}$. This defines the wages $W$ as a function of the productivity cutoffs and the price index $P$. Using the decomposition $\frac{L_{j}^{1}+L_{j}^{2}}{L_{j^{\prime}}^{1}+L_{j^{\prime}}^{2}}=\frac{L_{j}^{2}}{L_{j^{\prime}}^{2}} \frac{1}{L_{j^{\prime}}^{1} / L_{j^{\prime}}^{2}+1}+\frac{L_{j}^{1}}{L_{j^{\prime}}^{1}}\left(1-\frac{1}{L_{j^{\prime}}^{1} / L_{j^{\prime}}^{2}+1}\right)$, together with (1)-(2) and (4)-(7), the equilibrium conditions for the relative wages can be written as

$$
\begin{aligned}
\frac{\bar{L}_{b f}}{\bar{L}_{b m}}=\frac{W_{b m}}{W_{b f}}\left[\frac{\beta_{1}}{1-\beta_{1}}+\left(\frac{\beta_{2}}{1-\beta_{2}}-\frac{\beta_{1}}{1-\beta_{1}}\right) \frac{1}{1+\frac{\alpha_{1}\left(1-\beta_{1}\right)}{\alpha_{2}\left(1-\beta_{2}\right)} \frac{R_{1}}{R_{2}}}\right] \\
\frac{\bar{L}_{b f}}{\bar{L}_{w f}}=\frac{W_{w f}}{W_{b f}}\left[\frac{\alpha_{1} \beta_{1}}{\left(1-\alpha_{1}\right) \varpi_{1}}+\left(\frac{\alpha_{2} \beta_{2}}{\left(1-\alpha_{2}\right) \varpi_{2}}-\frac{\alpha_{1} \beta_{1}}{\left(1-\alpha_{1}\right) \varpi_{1}}\right) \frac{1}{1+\frac{\left(1-\alpha_{1}\right) \varpi_{1} R_{1}}{\left(1-\alpha_{2}\right) \varpi_{2}} \frac{R_{2}}{R_{2}}}\right] \\
\frac{\bar{L}_{w f}}{\bar{L}_{w m}}=\frac{W_{w m}}{W_{w f}}\left[\frac{\varpi_{1}}{1-\varpi_{1}}+\left(\frac{\varpi_{2}}{1-\varpi_{2}}-\frac{\varpi_{1}}{1-\varpi_{1}}\right) \frac{1}{1+\frac{\left(1-\alpha_{1}\right)\left(1-\varpi_{1}\right)}{\left(1-\alpha_{2}\right)\left(1-\varpi_{2}\right)} \frac{R_{1}}{R_{2}}}\right]
\end{aligned}
$$

The model is closed by assuming free entry. In particular, before learning their productivity $\varphi$, firms must be indifferent between entering the market or not. This requires expected profits (given $W, P$ and the productivity cutoffs) to equal the fixed cost $f_{e}$ of entry. Using the equations defining the productivity cutoffs, the labor market equilibrium conditions and the free entry condition, the equilibrium factor prices, price index and productivity cutoffs can be obtained.

In equilibrium, $\varphi_{1}^{*}<\varphi_{2}^{*}$ : low productivity firms use the traditional technology 1 while high productivity firms are willing to pay the higher fixed cost and use technology 2. Following Bustos (2011a), we focus on the case where the export cutoff $\varphi_{x}^{*}$ is between $\varphi_{1}^{*}$ and $\varphi_{2}^{*}$. Thus, in equilibrium, some but not all exporting firms use the modern technology. 


\subsection{Trade liberalization}

Trade liberalization can be modeled as a reduction in the trade $\operatorname{costs} \tau$. We obtain the following.

Proposition 1. A reduction in the tariff $\tau$ (i) lowers the export cutoff $\varphi_{x}^{*}$, (ii) lowers the technology adoption cutoff $\varphi_{2}^{*}$, (iii) increases women's relative wage in the blue collar category, (iv) leads to an increase in the relative number of female workers in the blue-collar category among firms that switch to the modern technology.

Trade liberalization makes exporting more attractive, which lowers the export cutoff $\varphi_{x}^{*}$. Since the modern technology with higher TFP is more efficient for producing the increased quantity for the export market, more firms adopt this technology (the cutoff $\varphi_{2}^{*}$ decreases). Because blue collar female workers are more productive under the modern technology, firms switching technology hire more of these workers, and their relative wage $\frac{W_{b f}}{W_{b m}}$ rises.

As mentioned above, the literature strongly suggests that technology upgrading that involves switching to computerized machinery in blue collar production processes should benefit women. By contrast, there does not seem to be any a priori reason why women should have higher or lower productivity in white collar tasks under either technology. In fact, Table 3 showed that employers did not express any gender preferences in hiring for "managers," by far the largest category of white-collar workers, suggesting that employers view men and women as similar type of workers in these tasks. Assuming that this is the case, we have the following result.

Proposition 2. If $\varpi_{1}=\varpi_{2}=\varpi$, then a reduction in the tariff $\tau$ (i) has no impact on women's relative wage or employment in the white collar category, (ii) raises the relative wage of white to blue collar workers if and only if

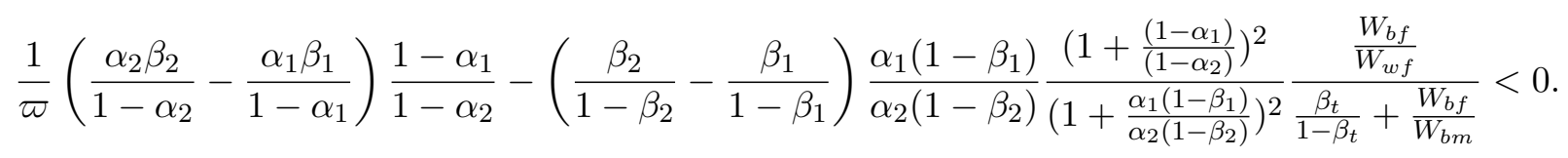

Part (i) of the proposition states that when technology choice does not affect gender differences in white collar tasks, trade liberalization does not affect women's relative outcomes in this category. In addition, part (ii) offers a contrast to some of the previous literature examining trade and skill upgrading. When labor inputs are multidimensional (e.g., differentiated by gender as well as occupation-specific skills), predictions on the changes in aggregate categories, such as the wage 
of all skilled workers, will tend to be theoretically ambiguous. The proposition shows that even if white collar tasks are relatively more important under the new technology $\left(\alpha_{1}>\alpha_{2}\right)$, whether total wages paid in this category rise or fall depends on the parameters of the model and the pre-existing relative wages of the various inputs. Thus, the impact of trade liberalization on white to blue collar wages is an empirical matter.

\section{Data}

The data used in this study come from the Encuesta Nacional de Empleo, Salarios, Tecnologia y Capacitacion (ENESTyC) [National Survey of Employment, Wages, Technology and Training], which is a survey carried out by the Mexican National Statistical Office (INEGI). The analysis focuses on two waves of the survey, implemented in 1992 and 2001, which were designed as independent cross-sections. The questions in the survey refer mainly to the year prior to the implementation of the survey (i.e., 1991 and 2000).

The ENESTyC survey was designed to be representative at the sectoral level within the manufacturing sector and it is possible to identify the sector in which firms operate at a very disaggregated level. There are 52 ramas (branches) of activity and around 200 clases (classes). ${ }^{14}$ Originally, the surveys not only included medium and large firms but also micro and small establishments. According to the INEGI classification micro establishments are those with less than 16 employees; small establishments have between 16 and 100 employees; medium establishments are those that have between 100 and 250 employees and finally, large establishments report more than 250 employees. ${ }^{15}$ However, in order to study the within firm effects of trade liberalization we create a balanced panel of firms between 1991 and 2000. Although the surveys were designed as independent cross-sections it is possible to link a subsample of firms over time, and we linked a total number of 938 firms between 1991 and 2000. Since the sample design of the ENESTyC surveys guarantees

\footnotetext{
${ }^{14}$ The industrial classification is based on the Clasificacion Mexicana de Actividades y Productos (CMAP) [Mexican Classification of Activities and Products]. Industries are grouped in 6-digit industries called clases (classes), 4-digit industries called ramas (branches), and 2-digit industries called divisiones (divisions).

${ }^{15}$ The survey is conducted at the establishment level. However, through out the analysis the words establishment, firm and plant will be used interchangeably.
} 
that medium and large firms are included with certainty, the average firm size (in terms of both sales and employment) is larger in the balanced panel (see Table B1 in appendix B).

Most importantly for our study firms provide information about sales, employment, raw materials, capital, as well as their ownership structure. ${ }^{16}$ In addition, firms report detailed information on export revenue, technology upgrading and female composition of the work force. In particular, firms report the share of export sales in total sales which allows us to determine the export status of firms in 2000 relative to their position in 1991 before the NAFTA agreement took place. Continuing exporters are firms that exported both in 1991 and 2000. New exporters are firms that did not export in 1991 but are exporting in 2000. Stop exporters are firms that exported in 1991 but do not export in 2000 and finally, non-exporters are firms that never exported during our sample period. Table B1 in the appendix shows that 34 percent of the firms in 2000 are continuing exporters and 24 percent are new exporters. Similar to previous studies in the literature (see Bernard and Jensen (1999)) we find that exporters are larger both in terms of employment and sales and are also more capital intensive (see Table B2 in the appendix). Interestingly we find significant differences between continuing exporters, new exporters and non-exporting firms. Continuing exporters are on average initially more productive (measured as value added per capita), employ a higher share of skilled labor, pay higher wages and pay higher wages to white collar workers relative to non-exporting firms. This is not the case for newly exporting firms. However, newly exporting firms do show a significant increase in wages and white collar wages between 1991 and $2000 .{ }^{17}$

We are interested in exploring the relationship between export status and technology upgrading. In order to do so we use measures of investment in technology provided by the ENESTyC survey. In particular, we use the log change in the value of machinery and equipment between 1991 and 2000. In addition, we make use of several characteristics of the machinery and equipment acquired that are detailed in the 2001 survey. In this survey firms are asked to provide information on the following aspects: whether the machinery and equipment acquired was computerized or automatic

\footnotetext{
${ }^{16}$ See Appendix A for a detailed description of the data and cleaning procedure and Table B1 in Appendix B for summary statistics of the variables used in the analysis.

${ }^{17}$ Overall, the change in female to male ratio in employment and wages among white collar workers between 1991 and 2000 was larger than the change among blue collar workers (see Table B1 in the appendix). However, as our results in the next section show, these changes in the white collar category do not seem to be linked to the trade liberalization process.
} 
(as opposed to manual or involving machinery tools), 61 percent of the firms; whether the machinery and equipment bought is new (as opposed to used), 69 percent of the firms and finally; whether the machinery and equipment was imported from developed countries, 53 percent of the firms. Overall, 35 percent of the firms in our sample bought new computerized machinery imported from developed countries.

Finally, a main feature of the ENESTyC survey is that it provides detailed information about labor outcomes disaggregated by gender and occupational category. The survey asks firms to report the number of employees and the wage bill according to four occupational categories: Directors, Managers, Specialized Workers and General Workers. ${ }^{18}$ In addition, firms are asked to detail within each occupational category the number of female/male employees as well as the corresponding wage bill.

\section{$5 \quad$ Empirical Results}

\subsection{Tariffs, Export Status, and Technology}

We start by documenting the relationship between trade liberalization and export status. According to Proposition 1, a reduction in trade costs lowers the export cutoff and induces firms at the margin to become exporters. To test this implication using our data, we estimate the following equation:

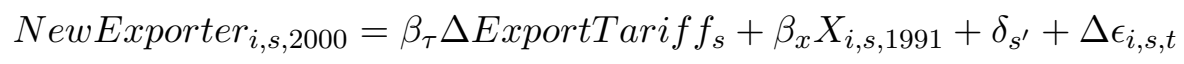

where $i$ denotes firm and $s$ refers to six-digit sector classification. NewExporter $r_{i, s, 2000}$ is a dummy variable that is equal to 1 for firms that did not export in 1991 but exported in 2000, and is equal to 0 for all other firms. $\Delta$ ExportTarif $f_{s}$ is the sectoral change in US tariffs from 1991 to

\footnotetext{
${ }^{18}$ Directors are "employees that make decisions related to activities in the areas of planning, direction, production policy, financing, marketing, internal organization." Managers include "employees that are not directly involved in the production process but apply scientific knowledge and methods in a variety of areas like technology, economics, sociology, industrial, and government related areas"; professionals (lawyers, chemists, engineers, accountants, etc.; technicians (lab employees, quality control technician, hydraulic technician, electronic technician, etc.); clerical employees; and supervisors (intermediate managers in the production process who "link higher end managers with those employees in the production process floor."
} 
2000. $X_{i, s, 1991}$ includes a set of initial firm characteristics that aim to control for firm size, capital intensity, R\&D intensity and foreign ownership. $\delta_{s^{\prime}}$ are two-digit sector fixed effects. Based on the implications of the model we expect $\beta_{\tau}$ to be negative and significant so that the probability of being a newly exporting firm is highest in industries that witnessed the largest declines in US tariffs.

Columns (1) and (2) in Table 4 show the results from estimating equation (11). Notice that we cluster standard errors at the cmap level to avoid any potential biases resulting from estimating the effect of an aggregate variable (tariff changes correspond to cmap level classification) on firm level outcomes. As expected, the probability of being a newly exporting firm is highest in those industries where the reduction in US tariffs is largest. In particular, our point estimate of -0.042 implies that a firm in an industry experiencing the average reduction in US tariffs (5.2 percentage points) is 21 percentage points more likely to be a newly exporting firm relative to firms that experienced zero tariff change. These results suggest that the impact of tariffs on the extensive margin, the entry of firms into the export market, plays an important role. ${ }^{19}$

We next explore the relationship between tariff changes and the intensive margin by regressing firm-level change in export revenue (as a share of total sales) on tariff changes. Our sample consists of firms who exported in 2000 (i.e., both firms that enter the export market and firms that were already exporting in 1991 and continue exporting in 2000). ${ }^{20}$ Columns (3) and (4) in Table 4 report the results. While the coefficients are negative in sign, we do not find a significant relationship between within-firm increase in exports and changes in US tariffs.

An important mechanism linking trade to worker outcomes in our model is the adoption of new technology. Following a tariff change, Proposition 1 predicts that firms that switch to the new technology will hire more blue-collar female workers. Should these effects appear primarily among continuing exporters or among firms that newly enter the export market? Depending on the position of the technology adoption and export cutoffs before and after the policy change, technology adoption may be more extensive among newly exporting firms or among continuing exporters. As

\footnotetext{
${ }^{19}$ In columns (1) and (2) the control group are continuing exporters, non-exporters and stop-exporters. However, similar results (coefficient -0.046(std. error 0.006)) are obtained if we focus on the sample of firms that were not exporting in 1991 (i.e., we directly compare newly exporters to non-exporters).

${ }^{20}$ Similar results are obtained if we only focus on the sample of continuing exporters.
} 
illustrated on Figure 3, if the export cutoff $\varphi_{x}^{*}$ and the technology adoption cutoff $\varphi_{2}^{*}$ are close to each-other and move together as the tariffs decline, almost all new exporters adopt technology 2 while most continuing exporters do not change their technology. In other cases, technology adoption may be more extensive among the continuing exporters. In order to investigate this issue, we estimate the following equation:

$$
\begin{aligned}
\Delta \text { Technology }_{i, s^{\prime}}= & \beta_{1} \text { ContinuingExporter }_{i, s^{\prime}, 2000}+\beta_{2} \text { NewExporter } s_{i, s^{\prime}, 2000} \\
& +\beta_{3} \text { StopExporter } s_{i, s^{\prime}, 2000}+\beta_{x} X_{i, 1991}+\delta_{s^{\prime}}+\epsilon_{i, s^{\prime}, 2000},
\end{aligned}
$$

where "ContinuingExporters" refers to firms who exported in both 1991 and 2000, "NewExporters" refers to firms who did not export in 1991 but exported in 2000, "StopExporters" refers to firms who stopped exporting, and the omitted category is "Non-Exporters," who did not export in both years. The rest of the RHS variables are the same as in equation (11). " $\Delta$ Technology" refers to the log change in the value of machinery and equipment between 1991 and $2000 .^{21}$ We refine this variable further by exploiting information in the 2001 survey regarding the type of technology purchased by the firm. In particular, our model considers technology upgrading towards less "brawn" intensive skills. One of the advantages of the ENESTyC survey is that it includes questions on the type of machinery and equipment introduced. We can therefore attempt to distinguish the mere acquisition of machinery from the type of technology upgrading in our model. In particular, we consider technology to be upgraded if the machinery and equipment acquired since 1999 is automatic/computerized (as opposed to manual or involving machinery tools), if it is new machinery (as opposed to used machinery), and if it is imported from developed countries.

Table 5 shows the results from estimating equation (12). Columns (1) and (2) show that new exporters are more likely to have undertaken large investment projects in machinery and equipment during 1991 to 2000 compared to non-exporters. In Columns (3)-(4) and (5)-(6), we separate the acquisition of machinery according to whether it involves technology upgrading as defined above. In Columns (3) and (4), the dependent variable is the product of the log difference in the value of machinery and equipment between 2000 and 1991 and a dummy variable that equals one if the

\footnotetext{
${ }^{21}$ Similar qualitative results although slightly weaker were obtained when we use log change in the value of machinery and equipment as share of total assets. Notice firm size is already accounted for by the additional control variables included in equation (12).
} 
firm upgraded its technology. The dependent variable in Columns (5) and (6) is defined similarly for non-upgraded technology. The results confirm that the difference between exporters and nonexporters comes from technology upgrading, as opposed to the mere purchase of machinery. While in Columns (5) and (6) there are no significant differences between exporters and non-exporters regarding non-upgraded machinery and equipment, Columns (3) and (4) show a very different picture with respect to upgraded machinery. In particular, the results show that newly exporting firms are particularly likely to upgrade their technology towards modern, less "brawn" intensive machinery and equipment. Therefore, since upgraded machinery reflects the technology change in our model, we expect our theoretical results on gender differences to appear mainly among new exporters where such technology adoption seems to be especially prevalent.

So far we have presented evidence on how trade liberalization induces firms to enter the export market and how these firms are more likely to invest in machinery and equipment. While skillupgrading is not our main focus, some previous studies find evidence that exporting firms employ more educated workers. Although we expect to find higher education levels in white collar tasks, in our model workers are differentiated by gender (gender-specific skills) as well as occupation-specific skills. Therefore, as Proposition 2(ii) suggests, we may find different results on the effect of trade liberalization on "skill" measured as the number of workers employed in blue-collar or white-collar occupations and their relative wages. We estimate the following equation which is similar to the previous estimating equation except that our dependent variable is now the growth rate in the ratio of white-collar workers to blue-collar workers hired.

$$
\begin{aligned}
\Delta \text { SkillRatio }_{i, s^{\prime}, 2000}= & \beta_{1} \text { ContinuingExporter }_{i, s^{\prime}, 2000}+\beta_{2} \text { NewExporter } s_{i, s^{\prime}, 2000} \\
& +\beta_{3} \text { StopExporter } s_{i, s^{\prime}, 2000}+\beta_{x} X_{i, s^{\prime}, 1991}+\delta_{s^{\prime}}+\epsilon_{i, s^{\prime}, 2000} .
\end{aligned}
$$

"Non-Exporters" are again the omitted category and the rest of the RHS variables are the same as in equation (12). $\Delta$ SkillRatio refers to the growth rate of the ratio of white-collar to blue-collar labor outcomes between 1991 and 2000. Table 6 reports the main results. The first three columns report results without including initial firm-level characteristics, while the next three columns report results including these variables. Both in terms of employment and wage bill (reported in columns (1) and (2)), we find little evidence of faster skill-upgrading in exporter firms. We do, however, consistently find that relative wage of white-collar workers to blue-collar workers grew 
faster in "New-Exporter" firms. For example, in column (3), the coefficient 0.110 indicates that the skill premium increased 11 percent faster in "New-Exporter" firms relative to "Non-Exporter" firms. ${ }^{22}$ Similar to the results we report here, Verhoogen (2008) also finds an increase in the ratio of white-collar to blue-collar wages but little skill-upgrading in terms of employment ratios. These results are consistent with our model of multi-dimensional labor inputs.

\subsection{Tariffs and Gender Labor Outcomes}

\subsubsection{Reduced-Form Effects of Tariffs on Gender Outcomes}

We now turn to our main empirical results on gender outcomes. A key implication of our model is that trade liberalization increases the number of new exporting firms and these firms adopt a new technology that increases the productivity of female workers in blue-collar tasks. Accordingly we should observe an increase in the relative wage of female workers in the blue collar category (Proposition 1(iii)). Similarly, we should observe larger increases in relative employment of female workers in blue collar tasks associated with tariff reductions (Proposition 1(iv)). By contrast if, as seems plausible, the new technology did not enhance the relative productivity of women in whitecollar tasks, we expect no effect on women's relative outcomes in this category (Proposition 2(i)). To test these predictions, we estimate the following equation:

$$
\Delta \text { FemaleRatio }_{i, s}=\beta_{\tau} \Delta \text { ExportTarif } f_{s}+\beta_{x} X_{i, s, 1991}+\delta_{s^{\prime}}+\Delta \epsilon_{i, s}
$$

where $i$ denotes firm and $s$ refers to sector. $\Delta$ Female Ratio ${ }_{i, s}$ refers to log change in the ratio of female to male outcomes for the three variables- employment, wage bill, and wage. ${ }^{23}$ Columns (1) to (3) of Table 7 refer to white-collar occupations while columns (4) to (6) refer to blue-collar

\footnotetext{
${ }^{22}$ In column (7) and (8) we examine whether the change in the ratio is due to the growth of white-collar wages or blue-collar wages. The results show that the larger increase in the skill premium is due to the larger increase in white-collar wage.

${ }^{23}$ As a sensitivity analysis we repeated the exercise using winsorized values of these female to male ratios at 1 and 99 percent as well as 2.5 and 97.5 percent of the distribution and all our main findings go through. Similarly, results are robust to dropping observations with lower/higher values than the 1 and 99 percentile or 2.5 and 97.5 percentile of the distribution.
} 
occupations. $^{24}$ As shown in the first three columns, we find no evidence that tariff reductions improved relative outcomes of women in white-collar occupations in terms of all three variables, employment share, wage bill share, and wage. By contrast, we find that reductions in tariffs are associated with larger increases in the growth of female employment and wage bill shares for bluecollar workers. For example, the coefficient -0.040 suggests that a firm in an industry experiencing the average reduction in US tariffs of 5.2 percentage points increased female employment share in blue-collar occupations by approximately 20 percent more than a firm experiencing zero tariff change. In terms of wage bill share, the effects are even larger, with the average tariff reduction causing a 24 percent larger increase in women's relative wage bill share.

These results strongly support our model: we find improving female outcomes exactly in the employment category where we expect the relative importance of "brawn" to decline as a result of improved technology.

\subsubsection{Alternative Channels}

The previous table showed that tariff reductions increased the employment and wage bill share of women in blue-collar occupations. We argued that this relationship was driven by the entry of exporting firms which invested in new machinery and equipment and that this new technology raised the relative productivity of female workers in blue-collar occupations. In this section we explore alternative channels which may be driving our results.

First of all, we note that any alternative story would have to explain both the differential change in female outcomes by export status and by occupation category (blue vs. white collar). For example, a supply-side model based on women's higher labor supply elasticity or the increase in women's education level over this period could explain an overall increase in relative wages, but would have a hard time explaining the differential changes we find. Only if women's education increased disproportionately in export industries or regions more exposed to trade and in blue

\footnotetext{
${ }^{24}$ Notice that the number of observations in the columns that refer to wage equations (columns (3) and especially (6)) are lower than the corresponding columns for employment and wage bill. The variable wage is defined as the ratio of wage bill to employment. If the company reports zero or missing female employment in a particular occupational category the wage cannot be computed.
} 
collar tasks could the education channel be driving our results. ${ }^{25}$ Of course, an increase in women's education could be the result of the mechanism we are proposing if additional training is needed to operate the new equipment. Thus, an increase in education could be part of our proposed channel. ${ }^{26}$

One possible alternative mechanism is the role of foreign direct investment (FDI). It may be the case that the new exporters are more likely to be foreign firms who not only bring newer technology but also less discriminatory attitudes towards hiring women. A priori, this is unlikely to drive our results for three reasons. First, only 8 percent of the new exporters represent FDI, suggesting that the majority of new exporters are domestic firms. ${ }^{27}$ Second, we do not find that foreign-owned and domestic companies report different attitudes towards hiring men over women. Foreign companies also express a preference for hiring men in the blue collar category (Table B3 in the Appendix). Third, more generally, how discrimination would affect the difference between the blue and white collar categories is theoretically ambiguous. For example, Goldin's (2002) model would predict discimination to be more important among white collar workers, in contrast to our findings. ${ }^{28}$

To test whether changes in foreign ownership can explain away our results, we estimate the following equation:

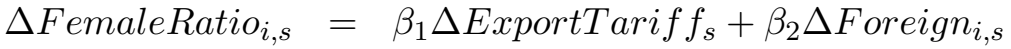

$$
\begin{aligned}
& +\beta_{3} \Delta \text { ExportTarif } f_{s} \times \Delta \text { Foreign }_{i, s}+\beta_{x} X_{i, s, 1991}+\delta_{s^{\prime}}+\Delta \epsilon_{i, s}
\end{aligned}
$$

where $\Delta$ Foreign $_{i, s}$ refers to the change in foreign ownership status. Following the official balance-

\footnotetext{
${ }^{25}$ Note that the idea that exports are correlated with education is not uncontroversial - Atkin (2011) argues that trade liberalization in Mexico caused a reduction in education levels because higher wages gave workers an incentive to drop out of school.

${ }^{26}$ We are not aware of the existence of data on school attainment by gender, federal state and employment category. However, we use data from INEGI-SEP on average schooling by gender and Federal State to produce Table B4 in the appendix. In there we show that education alone cannot explain the increase in wages experienced by sectors more exposed to trade.

${ }^{27}$ We follow the official balance-of-payments definition of FDI and define foreign investment as direct if the foreign investor owns $10 \%$ or more of the ordinary shares or voting power of the company.

${ }^{28}$ In Goldin (2002) workers care about how their abilities are perceived by outsiders, and discrimination is therefore more prevalent in jobs where there is more asymmetric information about the abilities required. Since physical strength in an obvious requirement in blue collar jobs, while asymmetric information for white collar jobs is likely to be large, this would predict discrimination to be more pervasive among white rather than blue collar workers.
} 
of-payment definition of FDI, we define foreign ownership equal to 1 if foreign ownership is above 10\%. The results are reported in Table 8. Adding the change in foreign ownership status reduces the size of our coefficients. For example, the effect of tariffs changes on wage bill share is reduced from -0.046 (Table 7, column 5) to -0.034 in column (5) of Table 8. While we do not find a significant difference in the tariff effect between those who did and did not switch foreign ownership status (for example, the interaction term is not statistically significant at conventional levels), the coefficient is somewhat larger for the firms who switched. ${ }^{29}$ To the extent that the larger effect reflected access to newer equipment and technology, as opposed to differences in attitudes towards gender as suggested by Table B3, this would be entirely consistent with our story. Taken together, these results bolster our confidence that changes in technology, and not changing discrimination against women, are driving our results.

Another possible channel is import tariffs. Reductions in import tariffs may subject domestic firms to competition and spur technological innovation (for example, as in Bloom et al. (2011) or Csillag and Koren (2011)). To the extent that the reductions in import and export tariffs are positively correlated across industries, we may be capturing the impact of import tariffs. We examine this possibility directly by replacing $\Delta$ ExportTarif $f_{s}$ with $\Delta$ ImportTarif $f_{s}$ and report the results in Table 9. ${ }^{30}$ As the first panel illustrates, there is no systematic relationship between import tariff reductions and women's relative outcomes. In the second panel, we include both export and import tariffs, and again show that the effect is driven by the former, with the coefficient estimates changing very little compared to Table 7.

\footnotetext{
${ }^{29}$ Similar wage results are obtained when using a continuous measure of foreign ownership share. In the case of employment and wage bill although the interaction term is significant, the size of the coefficient is very small to have a sizeable total effect. For example, the direct effect of tariff changes on wage bill share is -0.032 while the interaction is -0.001. The average firm experienced an increase in foreign ownership of 1.7 percentage points between 1991 and 2000 , therefore, for a given decline in tariffs, the average firm increased the female to male wage bill ratio by $0.034(=$ $0.032+(1.70 * 0.001))$ compared to the 0.032 effect of a firm that did not change foreign ownership over the sample period. Similar results are obtained if we exclude from the analysis foreign-owned firms that did not change their ownership percentage over the sample period.

${ }^{30}$ ImportTarif $f_{s}$ refers to tariffs on final goods. We do not have enough information (i.e., firm level percentage of intermediate inputs imported by sector) to test for the role of intermediate input tariffs.
} 


\subsubsection{Effect of Export Status and Technology on Gender Outcomes: Instrumental Variables}

We have shown that reductions in export tariffs are associated with larger within-firm increases in the relative employment and wage bill share of women in blue-collar occupations. We have also shown indirect evidence that the effect is working through the entry of new firms into the export sector who upgrade their technology. In this section we formally scale these effects on gender outcomes by regressing gender outcomes on new exporter status or technology upgrading, using tariff changes to instrument for these variables. As above, we measure technology upgrading with the log change in the value of machinery for firms who purchased new computerized equipment from developed countries. ${ }^{31}$ We estimate the following equations:

$$
\begin{gathered}
\Delta \text { FemaleRatio }_{i, s}=\beta_{\tau} \text { NewExporter } i, s, 2000+\beta_{x} X_{i, s, 1991}+\delta_{s}+\Delta \epsilon_{i, s} \\
\Delta \text { FemaleRatio }_{i, s}=\beta_{\tau} \Delta \text { Technology }{ }_{i, s}+\beta_{x} X_{i, s, 1991}+\delta_{s}+\Delta \epsilon_{i, s}
\end{gathered}
$$

Table 10 reports the results from this exercise. The bottom panel shows the results of the first stage for both equations. As already illustrated in Table 4, there is a strong robust relationship between new exporter status and tariff changes. Columns (4)-(6) of the first stage regressions show a similar picture for the effect of tariff changes on technology upgrading. The second stage results are reported in the top panel. We again find significant impacts of tariff changes on relative outcomes for women in blue-collar occupations. As expected from the theoretical model and our previous results we do not find any effect on women's labor outcomes in the white collar categories. ${ }^{32}$ The coefficients we estimate have the following interpretation. A 10 percentage point increase in the share of new exporters increases the growth of female employment and wage bill share by 9.6 and 11.2 percent respectively, and the growth of the female-male wage ratio by 2.9 percent. The second stage results for the technology regressions also confirm our earlier findings. Firms that upgrade machinery increase their relative employment of female workers and pay them a higher wage (although this last effect is not estimated precisely). Our point estimates imply that a 10 percent faster growth in the value of machinery increases the growth of female employment and

\footnotetext{
${ }^{31}$ In Table B5 in the Appendix we present results for all machinery as well as non-upgraded technology, confirming that the effects are driven by firms that upgraded their technology.

${ }^{32}$ Results are not reported for space considerations but are available upon request.
} 
wage bill share by 6.5 percent and 7.6 percent, respectively, and the growth of the female-male wage ratio by 2.4 percent.

\section{Conclusion}

We presented a model where trade liberalization induced exporting firms to upgrade their technology in a way that raised the relative productivity of women in blue-collar occupations. Our empirical findings using firm-level data from Mexico are consistent with the model. We found that firms experiencing larger declines in export tariffs were more likely to hire blue-collar women and to pay them higher wages. We did not find similar effects in white-collar occupations, where the relative importance of physically demanding skills is less likely to have changed. Consistent with the model, we showed that these improvement in blue-collar women's labor market outcomes were driven by firms newly entering the export markets who upgraded their technology towards new computerized production machinery.

These results suggest an important channel through which current trade liberalization efforts can affect gender inequality.

\section{Acknowledgements}

We would like to thank Yona Rubinstein, Nathan Nunn and Peter Morrow for their thoughtful discussions of an earlier version of the paper. We also want to thank Eric Verhoogen and seminar

participants at LSE, Dalhousie, and the LACEA-Conference of the Trade and Integration Growth Network, 18th Annual Empirical Investigations in International Trade. Carolina Villegas-Sanchez acknowledges financial support from Banco Sabadell.

\section{References}

Acemoglu, D. (2003). Patterns of skill premia. The Review of Economic Studies 70(2), 199-230.

Aguayo, E., J. Airola, C. Juhn, and C. Villegas-Sanchez (2013). Did trade liberalization help women? the case of mexico in the 1990s. Research in Labor Economics forthcoming. 
Alesina, A., P. Giuliano, and N. Nunn (2011). On the origins of gender roles: Women and the plough. working paper, Harvard University.

Amiti, M. and D. Davis (2012). Trade, firms, and wages: Theory and evidence. Review of Economic Studies 79(1), 1-36.

Atkin, D. (2011). Endogenous skill acquistion and export manufacturing in mexico. working paper, Yale University.

Attanasio, O., P. Goldberg, and N. Pavcnik (2004). Trade reforms and wage inequality in colombia. Journal of Development Economics 74(2), 331-366.

Autor, D., F. Levy, and R. Murnane (2003). The skill content of recent technological change: An empirical exploration. Quarterly Journal of Economics 118(4), 1279-1333.

Becker, G. (1957). The Economics of Discrimination. University of Chicago Press.

Behrman, J., N. Birdsall, and M. Székely (2000). Economics reform and wage differentials in latin america. RES Working Papers 4235, Inter-American Development Bank, Research Department.

Bernard, A. and B. Jensen (1999). Exceptional exporter performance: Cause, effect, or both? Journal of International Economics 47(1), 1-25.

Black, S. and E. Brainerd (2004). Importing inequality? the impact of globalization on gender discrimination. Industrial and Labor Relations Review 57(4), 540-559.

Blau, F. and L. Kahn (1997). Swimming upstream: Trends in the gender wage differential in the 1980s. Journal of Labor Economics 15(1), 1-42.

Bloom, N., M. Draca, and J. Van Reenen (2011). Trade induced technical change: The impact of chinese imports on innovation, diffusion and productivity. working paper, Stanford University.

Brambilla, I., D. Lederman, and G. Porto (2012). Exports, export destinations, and skills. American Economic Review 102(7), 3406-3438.

Bustos, P. (2011a). Trade liberalization, exports, and technology upgrading: Evidence on the impact of mercosur on argentinian firms. American Economic Review 101(1), 304-340. 
Bustos, P. (2011b). The impact of trade on technology and skill upgrading: Evidence from argentina. working paper, Universitat Pompeu Fabra.

Cragg, M. and M. Epelbaum (1996). Why has wage dispersion grown in mexico? is it the incidence of reforms or the growing demand for skills? Journal of Development Economics 51(1), 99-116.

Csillag, M. and M. Koren (2011). Machines and machinist: Capital-skill complementarity from an international trade perspective. working paper, Central European University.

Duflo, E. (2003). Grandmothers and granddaughters: Old age pension and intra-household allocation in south africa. World Bank Economic Review 17(1), 1-25.

Duflo, E. (2012). Womens empowerment and economic development. Journal of Economic Literature 50(4), 1051-1079.

Ederington, J., J. Minier, and K. Troske (2010). Where the girls are: Trade and labor market segregation in colombia. University of Kentucky, Lexington, KY, USA.

Feliciano, Z. (2001). Workers and trade liberalization: The impact of trade reforms in mexico on wages and employment. Industrial and Labor Relations Review 55, 95-115.

Frias, J., D. Kaplan, and E. Verhoogen (2009). Exports and wage premia: Evidence from mexican employer-employee data. working paper, Columbia University.

Goldberg, P. and N. Pavcnik (2007). Distributional effects of globalization in developing countries. Journal of Economic Literature 45, 39-82.

Goldin, C. (2002). A pollution theory of discrimination: Male and female differences in occupations and earnings. NBER working paper 8985.

Hanson, G. and A. Harrison (1999). Trade liberalization and wage inequality in mexico. Industrial and Labor Relations Review 52(2), 271-288.

Helpman, E., O. Itskhoki, and S. Redding (2010). Inequality and unemployment in a global economy. Econometrica 4(78), 1239-1283.

Helpman, E., O. Itskhoki, and S. Redding (2011). Trade and labor market outcomes. National Bureau of Economic Research. 
Iacovone, L. and B. Javorcik (2010). Multi-product exporters: Product churning, uncertainty and export discoveries. The Economic Journal 120(544), 481-499.

Juhn, C., G. Ujhelyi, and C. Villegas-Sanchez (2013). Trade and gender inequality. American Economic Review Papers and Proceedings (forthcoming).

Melitz, M. (2003). The impact of trade on intra-industry reallocations and aggregate industry productivity. Econometrica 71(6), 1695-1725.

Ozler, S. (2000). Export orientation and female share of employment: Evidence from turkey. World Development 28(7), 1239-1248.

Pavcnik, N. (2003). What explains skill upgrading in less-developed countries? Journal of Development Economics 71(2), 311-328.

Qian, N. (2008). Missing women and the price of tea in china: The effect of sex-specific earnings on sex imbalance*. Quarterly Journal of Economics 123(3), 1251-1285.

Rendall, M. (2010). Brain versus brawn: The realization of women's comparative advantage. working paper, University of Zurich.

Revenga, A. (1997). Employment and wage effects of trade liberalization: The case of mexican manufacturing. Journal of Labor Economics 15(S3), 20-43.

Robertson, R. (2004). Relative prices and wage inequality: Evidence from mexico. Journal of International Economics 64(2), 387-409.

Thomas, D. (1990). Intra-household resource allocation: An inferential approach. The Journal of Human Resources 25(4), 635-664.

Topalova, P. and A. Khandelwal (2004). Trade liberalization and firm productivity: The case of india. The Review of Economics and Statistics 93(3), 995-1009.

Verhoogen, E. (2008). Trade, quality upgrading, and wage inequality in the mexican manufacturing sector. Quarterly Journal of Economics 123(2), 489-530.

Weinberg, B. (2000). Computer use and the demand for female workers. Industrial and Labor Relations Review 53, 290-308. 
Zabludovsky, J. (2005). El tlcan y la política de comercio exterior en méxico: una agenda inconclusa. INFORMACION COMERCIAL ESPANOLA-MONTHLY EDITION- 821, 59. 
Table 1: Tariffs

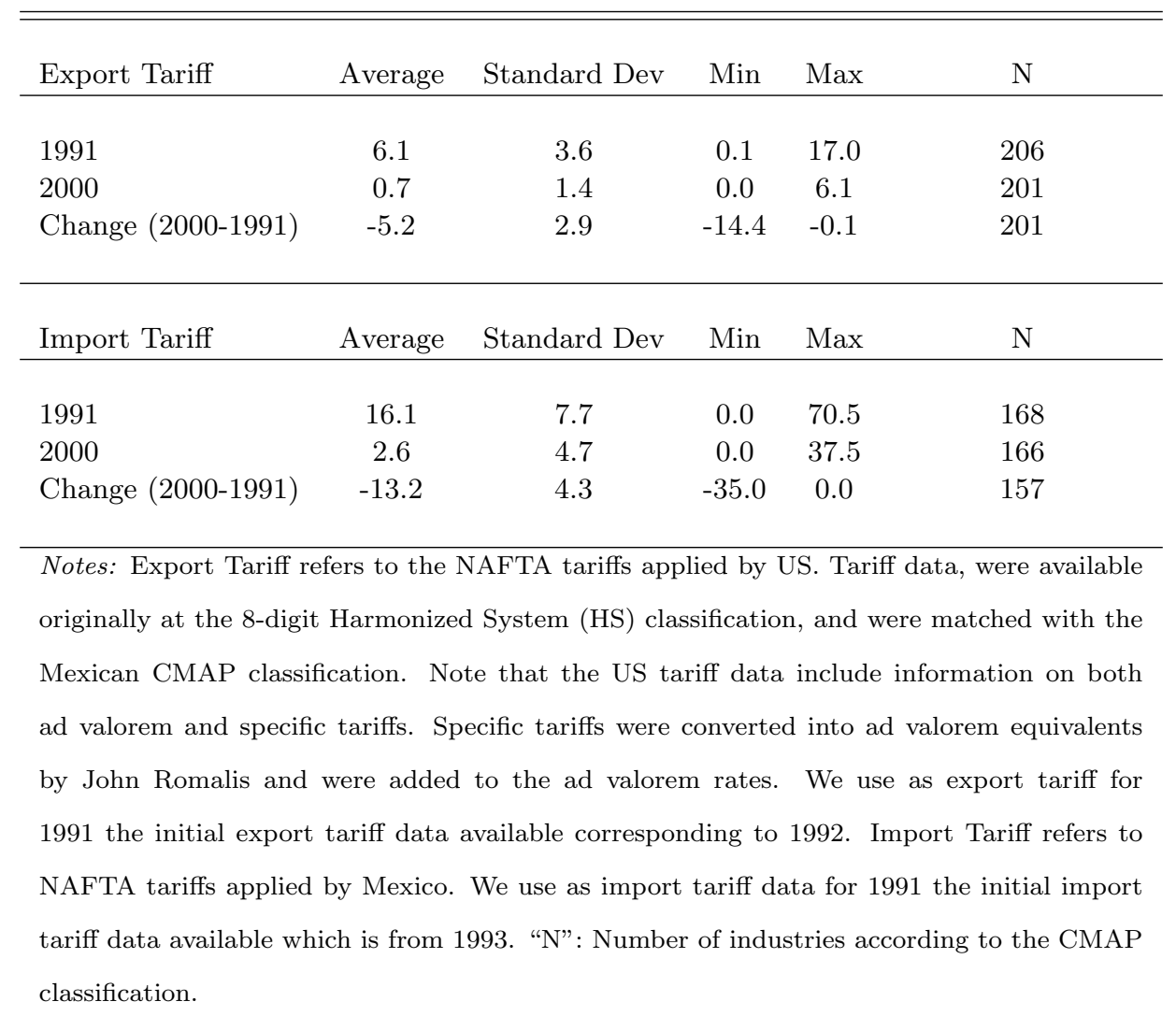


Table 2: Change in Share of Workers by Gender, 1991-2000

Panel A: Mexican Census Data: All Sectors

\begin{tabular}{|c|c|c|c|c|c|c|}
\hline & \multicolumn{3}{|c|}{ Employment Share } & \multicolumn{3}{|c|}{ Wage Bill Share } \\
\hline & Between & Within & Total & Between & Within & Total \\
\hline Women & 1.66 & 3.55 & 5.21 & 2.1 & 3.15 & 5.25 \\
\hline
\end{tabular}

Panel B: Mexican Census Data: Tradeable Sectors

\begin{tabular}{|c|c|c|c|c|c|c|}
\hline & \multicolumn{3}{|c|}{ Employment Share } & \multicolumn{3}{|c|}{ Wage Bill Share } \\
\hline & Between & Within & Total & Between & Within & Total \\
\hline Women & 2.49 & 3.22 & 5.71 & 2.09 & 2.6 & 5.09 \\
\hline
\end{tabular}

Panel C: ENESTyC Survey: Manufacturing Sectors

\begin{tabular}{|c|c|c|c|c|c|c|c|}
\hline & & \multicolumn{3}{|c|}{ Employment Share } & \multicolumn{3}{|c|}{ Wage Bill Share } \\
\hline & & Between & Within & Total & Between & Within & Total \\
\hline \multirow[t]{3}{*}{ Women } & White & 0.92 & 0.75 & 1.67 & 1.02 & 2.49 & 3.51 \\
\hline & Blue & 1.97 & 1.32 & 3.29 & 1.87 & 1.60 & 3.46 \\
\hline & Total & 1.64 & 1.25 & 2.89 & 1.33 & 2.21 & 3.55 \\
\hline
\end{tabular}


Table 3: Employer Preferences in Hiring by Occupational Category

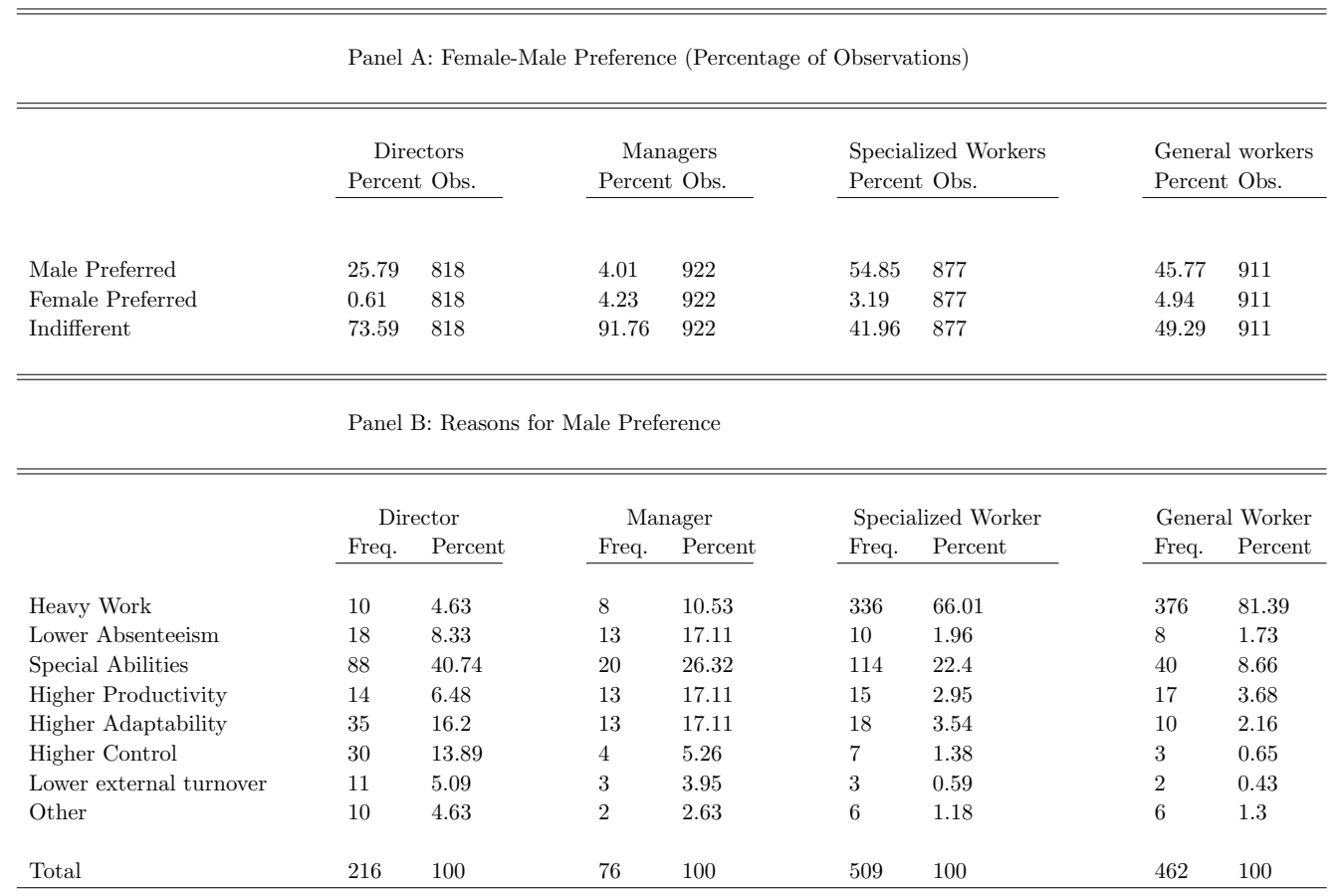

Notes: Panel A reports the percentage of firms that expressed a gender preference when hiring according to occupational category in 2000. Obs. refers to the total number of firms and it varies across occupational categories because it is based on those firms that hired in that year and occupational category (only firms that hired were asked about their gender preferences). Panel B reports the distribution of firms according to the main reasons expressed in 2000 for preferring men over women according to occupational category. 
Table 4: Tariff Changes and Exports

Dependent variable: Change in Export Status and Percentage of Exports

\begin{tabular}{|c|c|c|c|c|}
\hline & $\begin{array}{l}\text { NewExporter } \\
(1)\end{array}$ & $\begin{array}{l}\text { NewExporter } \\
(2)\end{array}$ & $\begin{array}{l}\Delta \text { ShareExports } \\
(3)\end{array}$ & $\begin{array}{l}\Delta \text { ShareExports } \\
\text { (4) }\end{array}$ \\
\hline$\Delta$ Export Tariff & $\begin{array}{l}-0.038^{* * *} \\
(0.008)\end{array}$ & $\begin{array}{l}-0.042^{* * *} \\
(0.008)\end{array}$ & $\begin{array}{l}0.017 \\
(0.431)\end{array}$ & $\begin{array}{l}-0.227 \\
(0.445)\end{array}$ \\
\hline $\ln (K / V A)_{i n i t}$ & & $\begin{array}{l}-0.023^{*} \\
(0.012)\end{array}$ & & $\begin{array}{l}-0.682 \\
(0.894)\end{array}$ \\
\hline $\ln (V A)_{i n i t}$ & & $\begin{array}{l}-0.004 \\
(0.009)\end{array}$ & & $\begin{array}{l}2.667^{* *} \\
(1.074)\end{array}$ \\
\hline R\&Dshare ${ }_{\text {init }}$ & & $\begin{array}{l}-0.001 \\
(0.001)\end{array}$ & & $\begin{array}{l}-0.103 \\
(0.072)\end{array}$ \\
\hline Foreign $_{\text {init }}$ & & $\begin{array}{l}-0.075^{*} \\
(0.040)\end{array}$ & & $\begin{array}{l}5.780 * * \\
(2.063)\end{array}$ \\
\hline Observations & 920 & 904 & 527 & 516 \\
\hline $\mathrm{R}^{2}$ & .054 & .068 & .052 & .097 \\
\hline Sector2dig Fixed Effects & Yes & Yes & Yes & Yes \\
\hline
\end{tabular}

Notes: Standard errors clustered at cmap level in parentheses. New Exporter refers to those firms that did not export in 1991 but are exporting in 2000. $\Delta$ ShareExports refers to the change between 2000 and 1991 in the share of export revenue in total sales. Columns (1) and (2) include all firms in the analysis. Columns (3) and (4) refer only to those firms that report export revenue in 2000. $\Delta$ Export Tariff indicates the change in sectoral tariffs (6-digit sector classification) applied by the US between 2000 and 1991. $\ln (K / V A)_{\text {init }}$ is the log of total assets to value added in 1991. $\ln (V A)_{\text {init }}$ is the $\log$ value added

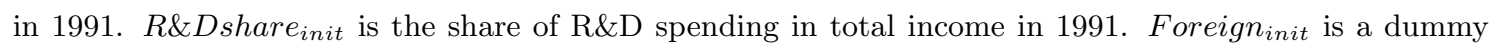
variable that takes the value of one if the firm was more than 10 percent owned by foreign-owned investors in 1991 and zero otherwise. ***, **, *, denote significance at 1\%,5\%,10\% levels. 
Table 5: Export Status and Technology Upgrading

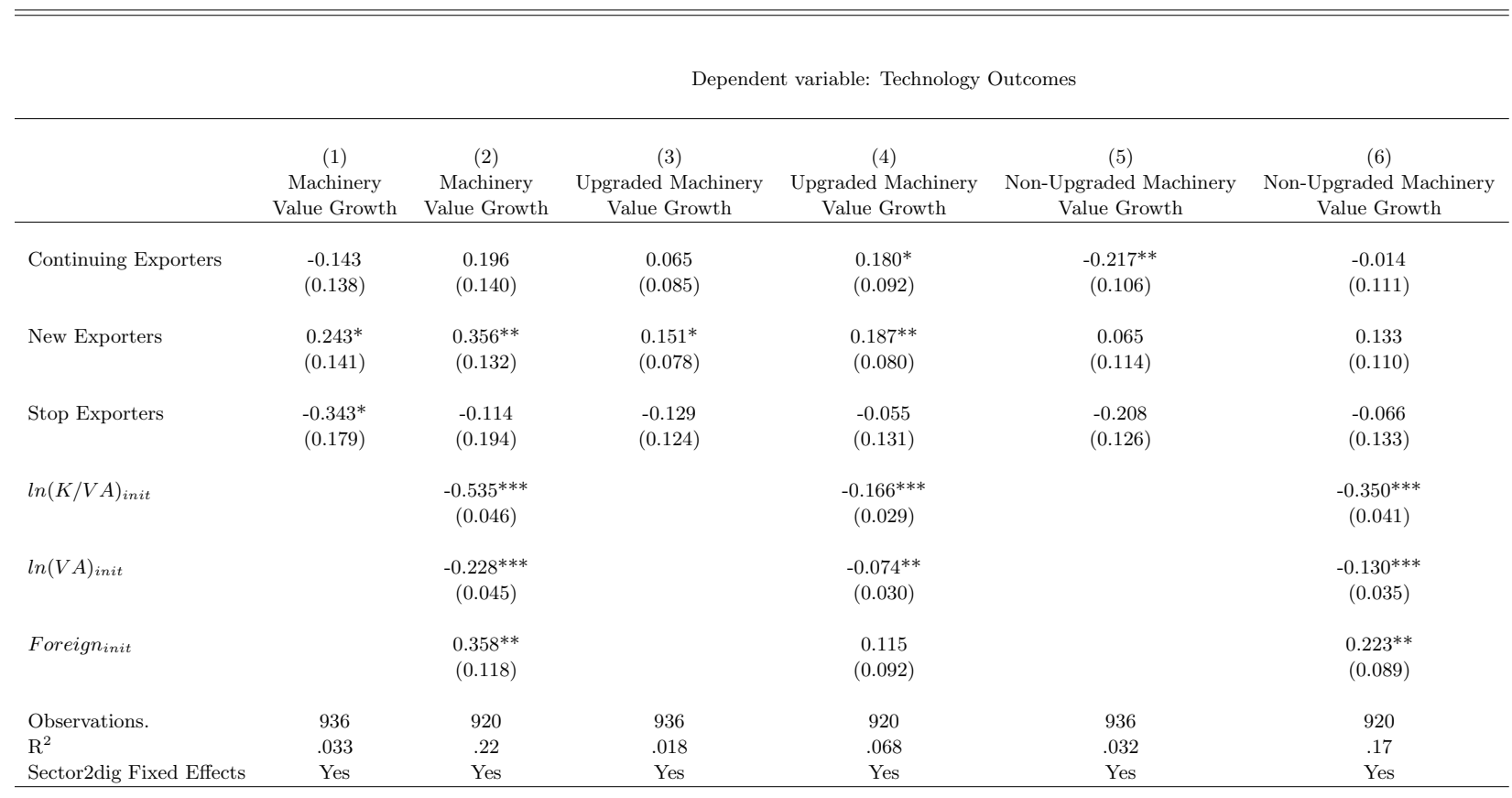

Notes: Standard errors clustered at cmap level in parentheses. Continuing exporters are those firms that exported in 1991 and 2000. New exporters are those firms that did not export in 1991 but export in 2000. Stop Exporters are firms that exported in 1991 but do not export in 2000. The omitted category is Non-Exporter. Machinery Value Growth is the log change in the value of machinery and equipment between 1991 and 2000. Upgraded Machinery Growth refers to the product of the $\log$ difference in the value of machinery and equipment between 2000 and 1991 and a dummy variable that equals one if the machinery and equipment acquired since 1999 is automatic/computerized and it is new machinery imported from developed countries. The Non-Upgraded Machinery equals one if the machinery and equipment acquired since 1999 is not automatic/computerized or it is not new machinery imported from developed countries. $\ln (K / V A)_{\text {init }}$ is the $\log$ of total assets to value added in 1991. $\ln (V A)_{\text {init }}$ is the $\log$ value added in 1991. Foreign $n_{\text {init }}$ is a dummy variable that takes the value of one if the firm was more than 10 percent owned by foreign-owned investors in 1991 and zero otherwise. $* * *, * *, *$, denote significance at $1 \%, 5 \%, 10 \%$ levels. 
Table 6: Export Status and Skill Upgrading

\begin{tabular}{|c|c|c|c|c|c|c|c|c|}
\hline & \multicolumn{8}{|c|}{ Dependent variable: Growth in White and Blue Labor Outcomes } \\
\hline & \multicolumn{6}{|c|}{ Ratio } & \multicolumn{2}{|c|}{ Level } \\
\hline & $\begin{array}{l}\text { White-Blue } \\
\text { Employment } \\
\text { Growth } \\
(1)\end{array}$ & $\begin{array}{c}\text { White-Blue } \\
\text { Wage Bill } \\
\text { Growth } \\
(2)\end{array}$ & $\begin{array}{c}\text { White-Blue } \\
\text { Wage } \\
\text { Growth } \\
(3)\end{array}$ & $\begin{array}{l}\text { White-Blue } \\
\text { Employment } \\
\text { Growth } \\
(4)\end{array}$ & $\begin{array}{c}\text { White-Blue } \\
\text { Wage Bill } \\
\text { Growth } \\
(5)\end{array}$ & $\begin{array}{c}\text { White-Blue } \\
\text { Wage } \\
\text { Growth } \\
(6)\end{array}$ & $\begin{array}{c}\text { White } \\
\text { Wage } \\
\text { Growth } \\
(7)\end{array}$ & $\begin{array}{c}\text { Blue } \\
\text { Wage } \\
\text { Growth } \\
(8)\end{array}$ \\
\hline Continuing Exporter & $\begin{array}{c}-0.096 \\
(0.087)\end{array}$ & $\begin{array}{l}-0.005 \\
(0.095)\end{array}$ & $\begin{array}{c}0.037 \\
(0.044)\end{array}$ & $\begin{array}{c}-0.120 \\
(0.098)\end{array}$ & $\begin{array}{l}-0.060 \\
(0.105)\end{array}$ & $\begin{array}{c}-0.006 \\
(0.048)\end{array}$ & $\begin{array}{l}-0.001 \\
(0.043)\end{array}$ & $\begin{array}{c}0.015 \\
(0.031)\end{array}$ \\
\hline New Exporter & $\begin{array}{l}-0.092 \\
(0.087)\end{array}$ & $\begin{array}{c}0.030 \\
(0.097)\end{array}$ & $\begin{array}{c}0.110^{* *} \\
(0.048)\end{array}$ & $\begin{array}{c}-0.091 \\
(0.090)\end{array}$ & $\begin{array}{c}0.025 \\
(0.099)\end{array}$ & $\begin{array}{c}0.092^{*} \\
(0.049)\end{array}$ & $\begin{array}{l}0.075^{*} \\
(0.045)\end{array}$ & $\begin{array}{c}-0.013 \\
(0.027)\end{array}$ \\
\hline Stop Exporter & $\begin{array}{l}-0.053 \\
(0.165)\end{array}$ & $\begin{array}{l}-0.070 \\
(0.183)\end{array}$ & $\begin{array}{c}0.015 \\
(0.074)\end{array}$ & $\begin{array}{c}-0.037 \\
(0.170)\end{array}$ & $\begin{array}{c}-0.074 \\
(0.187)\end{array}$ & $\begin{array}{c}-0.028 \\
(0.072)\end{array}$ & $\begin{array}{l}-0.024 \\
(0.068)\end{array}$ & $\begin{array}{c}0.002 \\
(0.037)\end{array}$ \\
\hline$R \& D$ share init $_{1}$ & & & & $\begin{array}{c}0.001 \\
(0.002)\end{array}$ & $\begin{array}{l}-0.000 \\
(0.002)\end{array}$ & $\begin{array}{c}0.001 \\
(0.001)\end{array}$ & $\begin{array}{c}0.001 \\
(0.001)\end{array}$ & $\begin{array}{c}-0.000 \\
(0.001)\end{array}$ \\
\hline $\ln (K / V A)_{\text {init }}$ & & & & $\begin{array}{c}0.015 \\
(0.025)\end{array}$ & $\begin{array}{c}0.030 \\
(0.026)\end{array}$ & $\begin{array}{c}0.009 \\
(0.014)\end{array}$ & $\begin{array}{l}0.025^{*} \\
(0.014)\end{array}$ & $\begin{array}{c}0.016 \\
(0.010)\end{array}$ \\
\hline $\ln (V A)_{\text {init }}$ & & & & $\begin{array}{l}-0.022 \\
(0.031)\end{array}$ & $\begin{array}{c}0.029 \\
(0.035)\end{array}$ & $\begin{array}{c}0.032^{* *} \\
(0.015)\end{array}$ & $\begin{array}{c}0.039^{* *} \\
(0.014)\end{array}$ & $\begin{array}{c}0.007 \\
(0.008)\end{array}$ \\
\hline Foreign init & & & & $\begin{array}{c}0.104 \\
(0.069)\end{array}$ & $\begin{array}{c}0.105 \\
(0.084)\end{array}$ & $\begin{array}{c}0.049 \\
(0.050)\end{array}$ & $\begin{array}{c}0.063 \\
(0.043)\end{array}$ & $\begin{array}{c}0.014 \\
(0.027)\end{array}$ \\
\hline Observations & 933 & 933 & 928 & 917 & 917 & 912 & 917 & 917 \\
\hline $\mathrm{R}^{2}$ & .032 & .02 & .013 & .035 & .023 & .021 & .028 & .026 \\
\hline Sector2dig Fixed Effects & Yes & Yes & Yes & Yes & Yes & Yes & Yes & Yes \\
\hline
\end{tabular}

Notes: Standard errors clustered at cmap level in parentheses. Continuing exporters are those firms that exported in 1991 and 2000. New exporters are those firms that did not export in 1991 but export in 2000. Stop Exporters are firms that exported in 1991 but do not export in 2000. The omitted category is Non-Exporter. Employment White-Blue refers to the growth in white to blue employment ratios between 1991 and 2000. Wage Bill White-Blue is the growth in white to blue wage bill ratios between 1991 and 2000. Wage White-Blue is the growth in white to blue wage ratios between 1991 and 2000. The wage is computed as the ratio of Wage Bill to Employment. The growth rate is computed as $\ln (($ white - blueratio $)+0.001)-\ln ((\text { white }- \text { blueratio })+0.001)_{t-1} \cdot \ln (K / V A)_{\text {init }}$ is the log of total assets to value added in 1991. $\ln (V A)_{\text {init }}$ is the log value added in 1991. R\&Dshare init $_{\text {in }}$ is the share of R\&D spending in total income in $1991 . F_{\text {oreign }}$ init is a dummy variable that takes the value of one if the firm was more than 10 percent owned by foreign-owned investors in 1991 and zero otherwise. $* * *, * *, *$, denote significance at $1 \%, 5 \%, 10 \%$ levels. 
Table 7: Reduced Form: Tariff Changes and Female-Male Labor Outcomes

Dependent variable: Growth in Female-Male Labor Ratios

\begin{tabular}{|c|c|c|c|c|c|c|}
\hline & \multicolumn{3}{|c|}{ White Collar } & \multicolumn{3}{|c|}{ Blue Collar } \\
\hline & $\begin{array}{c}\text { Female-Male } \\
\text { Employment } \\
\text { Growth } \\
(1)\end{array}$ & $\begin{array}{c}\text { Female-Male } \\
\text { Wage Bill } \\
\text { Growth } \\
(2)\end{array}$ & $\begin{array}{c}\text { Female-Male } \\
\text { Wage } \\
\text { Growth } \\
(3) \\
\end{array}$ & $\begin{array}{c}\text { Female-Male } \\
\text { Employment } \\
\text { Growth } \\
(4)\end{array}$ & $\begin{array}{l}\text { Female-Male } \\
\text { Wage Bill } \\
\text { Growth } \\
(5)\end{array}$ & $\begin{array}{c}\text { Female-Male } \\
\text { Wage } \\
\text { Growth } \\
(6)\end{array}$ \\
\hline$\Delta$ Export Tariff & $\begin{array}{c}0.020 \\
(0.025)\end{array}$ & $\begin{array}{c}0.012 \\
(0.024)\end{array}$ & $\begin{array}{l}-0.010 \\
(0.007)\end{array}$ & $\begin{array}{c}-0.040^{*} \\
(0.022)\end{array}$ & $\begin{array}{c}-0.046^{* *} \\
(0.021)\end{array}$ & $\begin{array}{c}-0.010^{*} \\
(0.005)\end{array}$ \\
\hline $\ln (K / V A)_{\text {init }}$ & $\begin{array}{c}0.026 \\
(0.040)\end{array}$ & $\begin{array}{c}0.021 \\
(0.039)\end{array}$ & $\begin{array}{l}-0.014 \\
(0.015)\end{array}$ & $\begin{array}{c}0.004 \\
(0.046)\end{array}$ & $\begin{array}{c}0.019 \\
(0.047)\end{array}$ & $\begin{array}{c}0.009 \\
(0.015)\end{array}$ \\
\hline $\ln (V A)_{\text {init }}$ & $\begin{array}{l}-0.028 \\
(0.041)\end{array}$ & $\begin{array}{l}-0.024 \\
(0.039)\end{array}$ & $\begin{array}{l}-0.005 \\
(0.017)\end{array}$ & $\begin{array}{l}-0.055 \\
(0.050)\end{array}$ & $\begin{array}{l}-0.058 \\
(0.051)\end{array}$ & $\begin{array}{l}-0.007 \\
(0.013)\end{array}$ \\
\hline$R \&$ Dhare $_{\text {init }}$ & $\begin{array}{c}0.009^{* *} \\
(0.003)\end{array}$ & $\begin{array}{c}0.008^{* *} \\
(0.003)\end{array}$ & $\begin{array}{c}-0.001 \\
(0.001)\end{array}$ & $\begin{array}{c}-0.001 \\
(0.004)\end{array}$ & $\begin{array}{l}-0.001 \\
(0.004)\end{array}$ & $\begin{array}{c}0.001 \\
(0.001)\end{array}$ \\
\hline Foreign $n_{\text {init }}$ & $\begin{array}{c}0.001 \\
(0.117)\end{array}$ & $\begin{array}{l}-0.001 \\
(0.114)\end{array}$ & $\begin{array}{c}0.010 \\
(0.063)\end{array}$ & $\begin{array}{l}-0.038 \\
(0.159)\end{array}$ & $\begin{array}{l}-0.005 \\
(0.163)\end{array}$ & $\begin{array}{c}0.032 \\
(0.051)\end{array}$ \\
\hline Observations & 899 & 898 & 862 & 895 & 895 & 562 \\
\hline $\mathrm{R}^{2}$ & .026 & .02 & .019 & .0095 & .012 & .021 \\
\hline Sector2dig Fixed Effects & Yes & Yes & Yes & Yes & Yes & Yes \\
\hline
\end{tabular}

Notes:Standard errors clustered at cmap level in parentheses. $\Delta$ Export Tariff indicates the change in sectoral tariffs (6-digit sector classification) applied by the US between 2000 and 1991. Columns (1) to (3) refer to the White-Collar category while columns (4) to (6) refer to the Blue-Collar category. Female-Male Employment growth refers to the growth in female to male employment ratios between 1991 and 2000. Female-Male Wage Bill is the growth in female to male wage bill ratios between 1991 and 2000. Female-Male wage is the growth in female to male wage ratios between 1991 and 2000. The wage is computed as the ratio of Wage Bill to Employment. The growth rate is computed as $\ln (($ female - maleratio $)+0.001)-\ln ((\text { female }- \text { maleratio })+0.001)_{t-1} \cdot \ln (K / V A)_{\text {init }}$ is the log of total assets to value added in 1991. $\ln (V A)_{\text {init }}$ is the $\log$ value added in 1991. $R \& D$ share $e_{i n i t}$ is the share of R\&D spending in total income in 1991. Foreign $n_{\text {init }}$ is a dummy variable that takes the value of one if the firm was more than 10 percent owned by foreign-owned investors in 1991 and zero otherwise. ${ }^{* * *}, * *, *$, denote significance at $1 \%, 5 \%, 10 \%$ levels. 
Table 8: Alternative Channel: Foreign Ownership

\begin{tabular}{|c|c|c|c|c|c|c|}
\hline & \multicolumn{6}{|c|}{ Dependent variable: Growth in Female-Male Labor Ratios } \\
\hline & \multicolumn{3}{|c|}{ White Collar } & \multicolumn{3}{|c|}{ Blue Collar } \\
\hline & $\begin{array}{c}\text { Female-Male } \\
\text { Employment } \\
\text { Growth } \\
(1)\end{array}$ & $\begin{array}{c}\text { Female-Male } \\
\text { Wage Bill } \\
\text { Growth } \\
(2)\end{array}$ & $\begin{array}{c}\text { Female-Male } \\
\text { Wage } \\
\text { Growth } \\
(3)\end{array}$ & $\begin{array}{c}\text { Female-Male } \\
\text { Employment } \\
\text { Growth } \\
(4)\end{array}$ & $\begin{array}{c}\text { Female-Male } \\
\text { Wage Bill } \\
\text { Growth } \\
(5)\end{array}$ & $\begin{array}{c}\text { Female-Male } \\
\text { Wage } \\
\text { Growth } \\
(6)\end{array}$ \\
\hline$\Delta$ ExportTariff $\times \Delta$ Foreign & $\begin{array}{c}-0.076^{* *} \\
(0.038)\end{array}$ & $\begin{array}{c}-0.053 \\
(0.048)\end{array}$ & $\begin{array}{c}0.019 \\
(0.026)\end{array}$ & $\begin{array}{c}-0.074 \\
(0.049)\end{array}$ & $\begin{array}{l}-0.070 \\
(0.050)\end{array}$ & $\begin{array}{c}0.019 \\
(0.017)\end{array}$ \\
\hline$\Delta$ Export Tariff & $\begin{array}{c}0.021 \\
(0.023)\end{array}$ & $\begin{array}{c}0.014 \\
(0.019)\end{array}$ & $\begin{array}{c}-0.007 \\
(0.008)\end{array}$ & $\begin{array}{l}-0.027 \\
(0.021)\end{array}$ & $\begin{array}{c}-0.034 \\
(0.021)\end{array}$ & $\begin{array}{c}-0.011^{* *} \\
(0.005)\end{array}$ \\
\hline$\Delta$ Foreign & $\begin{array}{c}-0.494^{*} \\
(0.281)\end{array}$ & $\begin{array}{l}-0.385 \\
(0.299)\end{array}$ & $\begin{array}{c}0.081 \\
(0.138)\end{array}$ & $\begin{array}{c}-0.039 \\
(0.388)\end{array}$ & $\begin{array}{c}0.034 \\
(0.396)\end{array}$ & $\begin{array}{c}0.233 \\
(0.157)\end{array}$ \\
\hline $\ln (K / V A)_{\text {init }}$ & $\begin{array}{c}-0.011 \\
(0.041)\end{array}$ & $\begin{array}{c}-0.001 \\
(0.040)\end{array}$ & $\begin{array}{l}-0.002 \\
(0.016)\end{array}$ & $\begin{array}{l}-0.004 \\
(0.051)\end{array}$ & $\begin{array}{c}0.016 \\
(0.054)\end{array}$ & $\begin{array}{c}0.018 \\
(0.016)\end{array}$ \\
\hline $\ln (V A)_{\text {init }}$ & $\begin{array}{c}-0.026 \\
(0.047)\end{array}$ & $\begin{array}{l}-0.016 \\
(0.044)\end{array}$ & $\begin{array}{c}0.003 \\
(0.017)\end{array}$ & $\begin{array}{c}-0.095^{*} \\
(0.048)\end{array}$ & $\begin{array}{c}-0.090^{*} \\
(0.048)\end{array}$ & $\begin{array}{c}0.003 \\
(0.015)\end{array}$ \\
\hline$R \& D$ share $_{\text {init }}$ & $\begin{array}{c}0.010^{* *} \\
(0.004)\end{array}$ & $\begin{array}{c}0.007^{*} \\
(0.004)\end{array}$ & $\begin{array}{l}-0.002 \\
(0.001)\end{array}$ & $\begin{array}{c}0.000 \\
(0.004)\end{array}$ & $\begin{array}{c}0.002 \\
(0.004)\end{array}$ & $\begin{array}{c}0.001 \\
(0.001)\end{array}$ \\
\hline Observations & 787 & 786 & 758 & 784 & 784 & 497 \\
\hline $\mathrm{R}^{2}$ & .029 & .019 & .012 & .018 & .021 & .041 \\
\hline Sector2dig Fixed Effects & Yes & Yes & Yes & Yes & Yes & Yes \\
\hline F-test & 0.076 & 0.369 & 0.500 & 0.145 & 0.098 & 0.088 \\
\hline
\end{tabular}

Notes:Standard errors clustered at cmap level in parentheses. $\Delta$ Export Tariff indicates the change in sectoral tariffs (6-digit sector classification) applied by the US between 2000 and 1991. Columns (1) to (3) refer to the White-Collar category while columns (4) to (6) refer to the Blue-Collar category. Female-Male Employment growth refers to the growth in female to male employment ratios between 1991 and 2000. Female-Male Wage Bill is the growth in female to male wage bill ratios between 1991 and 2000. Female-Male wage is the growth in female to male wage ratios between 1991 and 2000. The wage is computed as the ratio of Wage Bill to Employment. The growth rate is computed as $\ln (($ female - maleratio $)+0.001)-\ln ((\text { female }- \text { maleratio })+0.001)_{t-1} \cdot \ln (K / V A)_{\text {init }}$ is the $\log$ of total assets to value added in 1991. $\ln (V A)_{\text {init }}$ is the $\log$ value added in 1991. R\&Dshare init $_{\text {is }}$ the share of R\&D spending in total income in 1991. $\Delta$ Foreign is the change in ownership status between 1991 and $2000 . * * *, * *, *$, denote significance at $1 \%, 5 \%, 10 \%$ levels. 
Table 9: Alternative Channel: Import Tariffs

\begin{tabular}{|c|c|c|c|c|c|c|}
\hline & \multicolumn{6}{|c|}{ Dependent variable: Growth in Female-Male Labor Ratios } \\
\hline & \multicolumn{6}{|c|}{ Panel A: Import Tariffs } \\
\hline & \multicolumn{3}{|c|}{ White Collar } & \multicolumn{3}{|c|}{ Blue Collar } \\
\hline & $\begin{array}{c}\text { Female-Male } \\
\text { Employment } \\
\text { Growth } \\
(1) \\
\end{array}$ & $\begin{array}{c}\text { Female-Male } \\
\text { Wage Bill } \\
\text { Growth } \\
(2)\end{array}$ & $\begin{array}{c}\text { Female-Male } \\
\text { Wage } \\
\text { Growth } \\
(3) \\
\end{array}$ & $\begin{array}{c}\text { Female-Male } \\
\text { Employment } \\
\text { Growth } \\
(4)\end{array}$ & $\begin{array}{c}\text { Female-Male } \\
\text { Wage Bill } \\
\text { Growth } \\
(5)\end{array}$ & $\begin{array}{c}\text { Female-Male } \\
\text { Wage } \\
\text { Growth } \\
(6) \\
\end{array}$ \\
\hline$\Delta$ Import Tariff & $\begin{array}{l}-0.006 \\
(0.013)\end{array}$ & $\begin{array}{c}-0.001 \\
(0.012)\end{array}$ & $\begin{array}{c}0.004 \\
(0.007)\end{array}$ & $\begin{array}{c}0.018 \\
(0.019)\end{array}$ & $\begin{array}{c}0.017 \\
(0.020)\end{array}$ & $\begin{array}{l}-0.005 \\
(0.005)\end{array}$ \\
\hline $\ln (K / V A)_{\text {init }}$ & $\begin{array}{c}0.004 \\
(0.036)\end{array}$ & $\begin{array}{c}0.010 \\
(0.036)\end{array}$ & $\begin{array}{l}-0.003 \\
(0.016)\end{array}$ & $\begin{array}{c}0.008 \\
(0.049)\end{array}$ & $\begin{array}{c}0.022 \\
(0.049)\end{array}$ & $\begin{array}{c}0.010 \\
(0.015)\end{array}$ \\
\hline $\ln (V A)_{\text {init }}$ & $\begin{array}{c}-0.039 \\
(0.042)\end{array}$ & $\begin{array}{l}-0.021 \\
(0.039)\end{array}$ & $\begin{array}{c}0.007 \\
(0.018)\end{array}$ & $\begin{array}{c}-0.062 \\
(0.054)\end{array}$ & $\begin{array}{l}-0.065 \\
(0.054)\end{array}$ & $\begin{array}{l}-0.006 \\
(0.015)\end{array}$ \\
\hline R\&Dshare init $_{\text {in }}$ & $\begin{array}{l}0.007^{*} \\
(0.004)\end{array}$ & $\begin{array}{c}0.006 \\
(0.004)\end{array}$ & $\begin{array}{c}-0.001 \\
(0.001)\end{array}$ & $\begin{array}{l}-0.002 \\
(0.005)\end{array}$ & $\begin{array}{l}-0.001 \\
(0.005)\end{array}$ & $\begin{array}{c}0.001 \\
(0.001)\end{array}$ \\
\hline Foreign $_{\text {init }}$ & $\begin{array}{l}-0.047 \\
(0.124)\end{array}$ & $\begin{array}{l}-0.023 \\
(0.118)\end{array}$ & $\begin{array}{c}0.031 \\
(0.067)\end{array}$ & $\begin{array}{c}-0.098 \\
(0.169)\end{array}$ & $\begin{array}{l}-0.071 \\
(0.171)\end{array}$ & $\begin{array}{c}0.011 \\
(0.051)\end{array}$ \\
\hline $\begin{array}{l}\text { Observations } \\
\mathrm{R}^{2} \\
\text { Sector2dig Fixed Effects }\end{array}$ & $\begin{array}{l}837 \\
.023 \\
\text { Yes }\end{array}$ & $\begin{array}{l}836 \\
.019 \\
\text { Yes } \\
\end{array}$ & $\begin{array}{l}803 \\
.019 \\
\text { Yes } \\
\end{array}$ & $\begin{array}{c}833 \\
.0092 \\
\text { Yes } \\
\end{array}$ & $\begin{array}{l}833 \\
.01 \\
\text { Yes } \\
\end{array}$ & $\begin{array}{l}510 \\
.021 \\
\text { Yes }\end{array}$ \\
\hline & \multicolumn{6}{|c|}{ Panel B: Export and Import Tariffs } \\
\hline & \multicolumn{3}{|c|}{ White Collar } & \multicolumn{3}{|c|}{ Blue Collar } \\
\hline & $\begin{array}{c}\text { Female-Male } \\
\text { Employment } \\
\text { Growth } \\
(1) \\
\end{array}$ & $\begin{array}{c}\text { Female-Male } \\
\text { Wage Bill } \\
\text { Growth } \\
(2)\end{array}$ & $\begin{array}{c}\text { Female-Male } \\
\text { Wage } \\
\text { Growth } \\
(3) \\
\end{array}$ & $\begin{array}{c}\text { Female-Male } \\
\text { Employment } \\
\text { Growth } \\
(4)\end{array}$ & $\begin{array}{l}\text { Female-Male } \\
\text { Wage Bill } \\
\text { Growth } \\
(5)\end{array}$ & $\begin{array}{c}\text { Female-Male } \\
\text { Wage } \\
\text { Growth } \\
(6)\end{array}$ \\
\hline$\Delta$ Export Tariff & $\begin{array}{c}0.023 \\
(0.024)\end{array}$ & $\begin{array}{c}0.017 \\
(0.023)\end{array}$ & $\begin{array}{l}-0.008 \\
(0.007)\end{array}$ & $\begin{array}{l}-0.044^{*} \\
(0.026)\end{array}$ & $\begin{array}{c}-0.050^{* *} \\
(0.025)\end{array}$ & $\begin{array}{l}-0.009 \\
(0.007)\end{array}$ \\
\hline$\Delta$ Import Tariff & $\begin{array}{l}-0.002 \\
(0.012)\end{array}$ & $\begin{array}{c}0.001 \\
(0.011)\end{array}$ & $\begin{array}{c}0.003 \\
(0.007)\end{array}$ & $\begin{array}{c}0.016 \\
(0.019)\end{array}$ & $\begin{array}{c}0.015 \\
(0.020)\end{array}$ & $\begin{array}{l}-0.005 \\
(0.005)\end{array}$ \\
\hline $\ln (K / V A)_{i n i t}$ & $\begin{array}{c}0.002 \\
(0.041)\end{array}$ & $\begin{array}{c}0.004 \\
(0.040)\end{array}$ & $\begin{array}{l}-0.009 \\
(0.016)\end{array}$ & $\begin{array}{l}-0.006 \\
(0.049)\end{array}$ & $\begin{array}{c}0.008 \\
(0.050)\end{array}$ & $\begin{array}{c}0.009 \\
(0.016)\end{array}$ \\
\hline $\ln (V A)_{\text {init }}$ & $\begin{array}{l}-0.038 \\
(0.040)\end{array}$ & $\begin{array}{l}-0.023 \\
(0.038)\end{array}$ & $\begin{array}{c}0.007 \\
(0.018)\end{array}$ & $\begin{array}{l}-0.055 \\
(0.052)\end{array}$ & $\begin{array}{l}-0.056 \\
(0.052)\end{array}$ & $\begin{array}{l}-0.006 \\
(0.015)\end{array}$ \\
\hline$R \&$ Dhare $_{\text {init }}$ & $\begin{array}{c}0.011^{* *} \\
(0.004)\end{array}$ & $\begin{array}{c}0.009^{* *} \\
(0.004)\end{array}$ & $\begin{array}{l}-0.001 \\
(0.001)\end{array}$ & $\begin{array}{c}0.001 \\
(0.005)\end{array}$ & $\begin{array}{c}0.001 \\
(0.004)\end{array}$ & $\begin{array}{c}0.001 \\
(0.001)\end{array}$ \\
\hline Foreign $_{\text {init }}$ & $\begin{array}{c}0.015 \\
(0.120)\end{array}$ & $\begin{array}{c}0.030 \\
(0.115)\end{array}$ & $\begin{array}{c}0.025 \\
(0.068)\end{array}$ & $\begin{array}{c}-0.069 \\
(0.165)\end{array}$ & $\begin{array}{l}-0.051 \\
(0.169)\end{array}$ & $\begin{array}{c}0.007 \\
(0.052)\end{array}$ \\
\hline $\begin{array}{l}\text { Observations. } \\
\mathrm{R}^{2} \\
\text { Sector2dig Fixed Effects }\end{array}$ & $\begin{array}{l}820 \\
.033 \\
\text { Yes }\end{array}$ & $\begin{array}{l}819 \\
.027 \\
\text { Yes }\end{array}$ & $\begin{array}{l}789 \\
.02 \\
\text { Yes }\end{array}$ & $\begin{array}{l}816 \\
.012 \\
\text { Yes }\end{array}$ & $\begin{array}{l}816 \\
.014 \\
\text { Yes }\end{array}$ & $\begin{array}{l}504 \\
.024 \\
\text { Yes }\end{array}$ \\
\hline
\end{tabular}

Notes: Standard errors clustered at cmap level in parentheses. $\Delta$ Export Tariff indicates the change in sectoral tariffs (6-digit sector classification) applied by the US between 2000 and 1991. $\Delta$ Import Tariff indicates the change in sectoral tariffs (6-digit sector classification) applied by Mexico between 2000 and 1991. Columns (1) to (3) refer to the White-Collar category while columns (4) to (6) refer to the Blue-Collar category. Female-Male Employment growth refers to the growth in female to male employment ratios between 1991 and 2000. Female-Male Wage Bill is the growth in female to male wage bill ratios between 1991 and 2000. Female-Male wage is the growth in female to male wage ratios between 1991 and 2000. The wage is computed as the ratio of Wage Bill to Employment. The growth rate is computed as $\ln (($ female - maleratio $)+0.001)-\ln (($ female maleratio $)+0.001)_{t-1} \cdot \ln (K / V A)_{\text {init }}$ is the $\log$ of total assets to value added in 1991. $\ln (K / V A)_{\text {init }}$ is the $\log$ of total assets to value added in 1991. $\ln (V A)_{\text {init }}$ is the log value added in 1991. R\&Dshare init $_{\text {is }}$ is the share of R\&D spending in total income in 1991. Foreign init is a dummy variable that takes the value of one if the firm was more than 10 percent owned by foreign-owned investors in 1991 and zero otherwise. ${ }^{* * *}, * *$, , denote significance at $1 \%, 5 \%, 10 \%$ levels. 
Table 10: New Exporters, Technology Upgrading and Female-Male Labor Outcomes (IV)

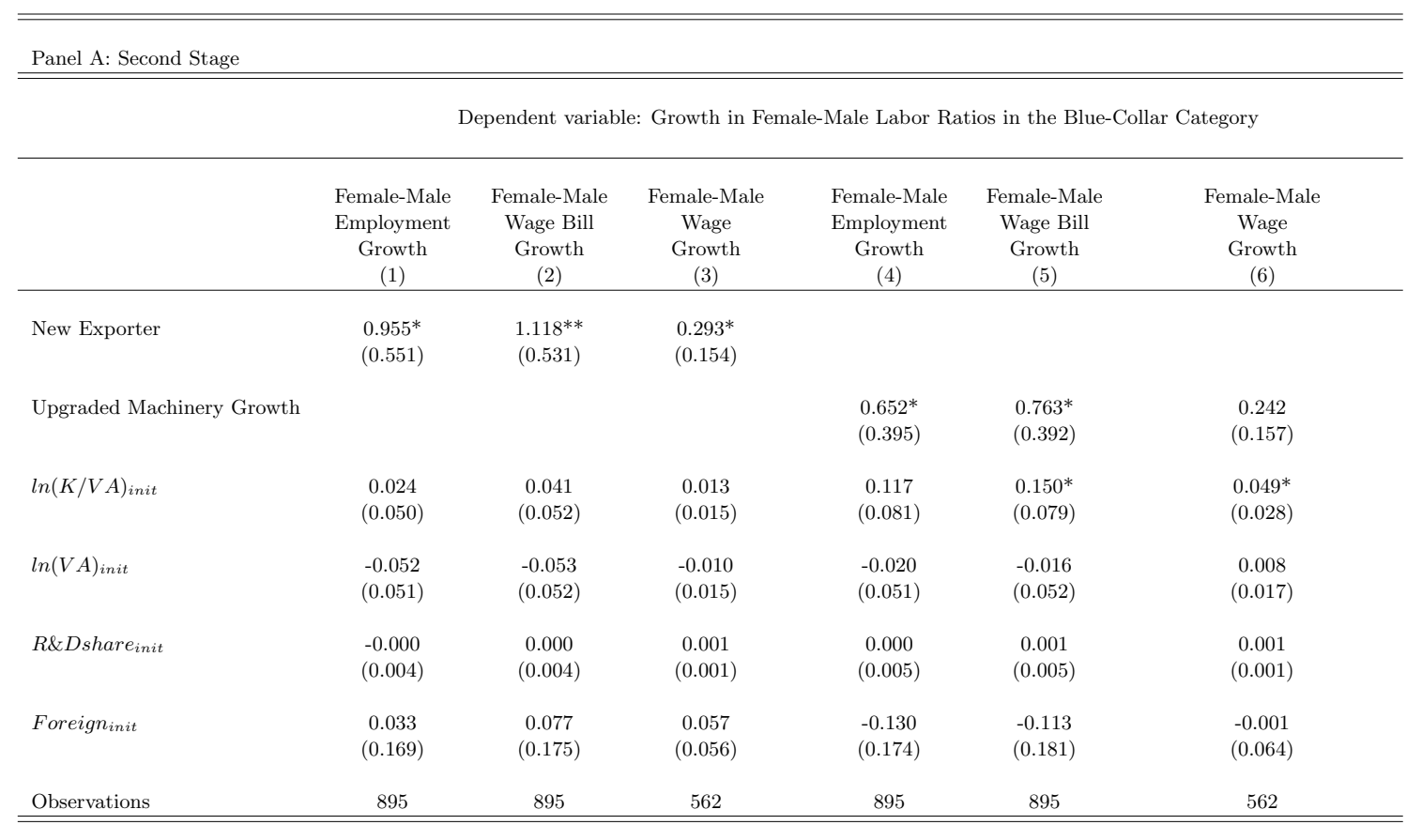

Panel B: First Stage

Dependent variable: New Exporter Dummy and Upgraded Machinery Value Growth

\begin{tabular}{|c|c|c|c|c|c|c|}
\hline & $\begin{array}{c}\text { New Exporter } \\
(1) \\
\end{array}$ & $\begin{array}{c}\text { New Exporter } \\
(2) \\
\end{array}$ & $\begin{array}{c}\text { New Exporter } \\
(3) \\
\end{array}$ & $\begin{array}{c}\text { Upgraded } \\
\text { Machinery } \\
\text { Value Growth } \\
(4)\end{array}$ & $\begin{array}{c}\text { Upgraded } \\
\text { Machinery } \\
\text { Value Growth } \\
(5)\end{array}$ & $\begin{array}{c}\text { Upgraded } \\
\text { Machinery } \\
\text { Value Growth } \\
(6)\end{array}$ \\
\hline$\Delta$ Export Tariff & $\begin{array}{c}-0.042^{* * *} \\
(0.008)\end{array}$ & $\begin{array}{c}-0.042^{* * *} \\
(0.008)\end{array}$ & $\begin{array}{c}-0.035^{* * *} \\
(0.051)\end{array}$ & $\begin{array}{c}-0.061^{* * *} \\
(0.012)\end{array}$ & $\begin{array}{c}-0.061^{* * *} \\
(0.012)\end{array}$ & $\begin{array}{c}-0.043^{* *} \\
(0.006)\end{array}$ \\
\hline $\begin{array}{l}\text { Observations. } \\
\text { Tests }\end{array}$ & 895 & 895 & 562 & 895 & 895 & 562 \\
\hline F-Test & 26.7 & 26.7 & 32.24 & 26.37 & 26.37 & 6.56 \\
\hline Anderson & 3.24 & 4.72 & 3.6 & 3.24 & 4.72 & 3.6 \\
\hline Cragg-Donald & 26.696 & 26.696 & 32.243 & 26.375 & 26.375 & 6.564 \\
\hline
\end{tabular}

Notes:Standard errors clustered at cmap level in parentheses. Panel A reports the results from the Second Stage. Panel B reports the results from the First Stage. $\Delta$ Export Tariff indicates the change in sectoral tariffs (6-digit sector classification) applied by the US between 2000 and 1991 . Upgraded Machinery Growth refers to the product of the log difference in the value of machinery and equipment between 2000 and 1991 and a dummy variable that equals one if the machinery and equipment acquired since 1999 is automatic/computerized and it is new machinery imported from developed countries. New Exporter is a dummy variables that equals one if the firm did not export in 1991 but exports in 2000. Female-Male Employment growth refers to the growth in female to male employment ratios between 1991 and 2000. Female-Male Wage Bill is the growth in female to male wage bill ratios between 1991 and 2000. Female-Male wage is the growth in female to male wage ratios between 1991 and 2000 . The wage is computed as the ratio of Wage Bill to Employment. The growth rate is computed as $\ln (($ female - maleratio $)+0.001)-\ln ((\text { female }- \text { maleratio })+0.001)_{t-1}$. $\ln (K / V A)_{i n i t}$ is the $\log$ of total assets to value added in 1991. $\ln (V A)_{i n i t}$ is the log value added in 1991. R\&Dshare init $_{\text {is }}$ is the share of R\&D spending in total income in 1991. Foreign $n_{\text {init }}$ is a dummy variable that takes the value of one if the firm was more than 10 percent owned by foreign-owned investors in 1991 and zero otherwise. ${ }^{* * *},{ }^{* *}, *$, denote significance at $1 \%, 5 \%, 10 \%$ levels. 


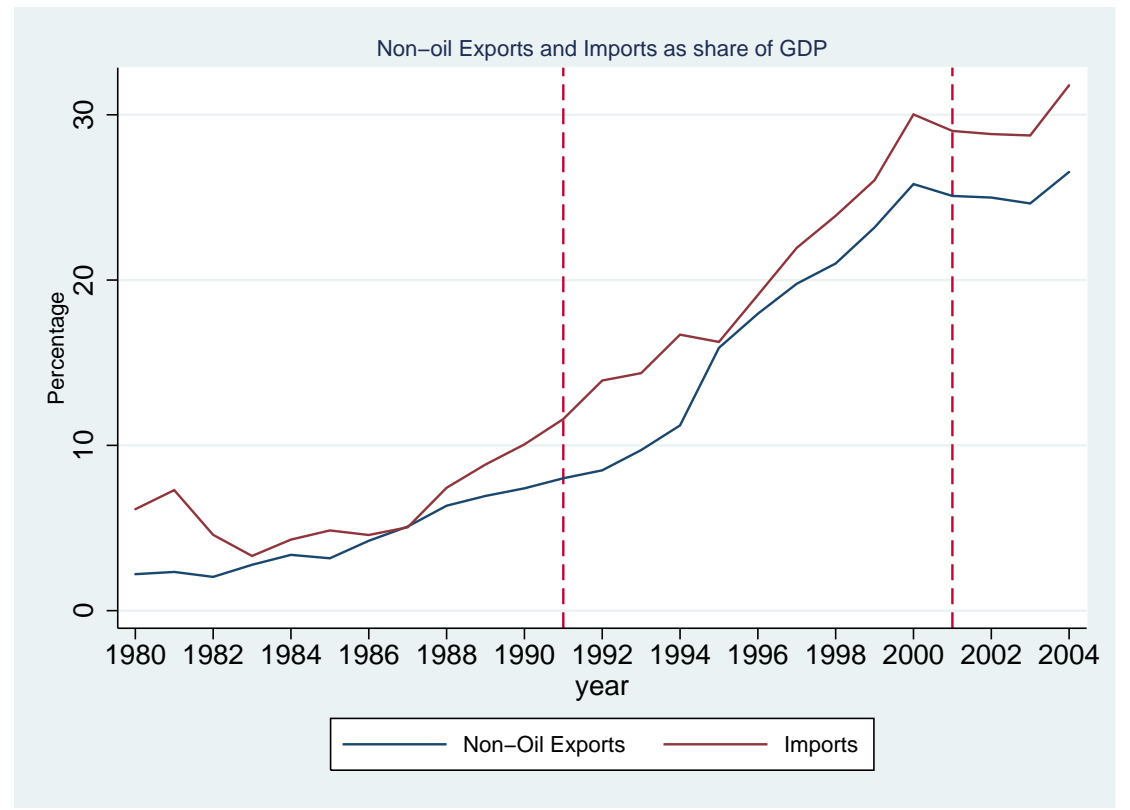

Figure 1: Mexican Imports and Exports. Source: Balance of Payment information provided by the Central Bank of Mexico (Banco de Mexico). 


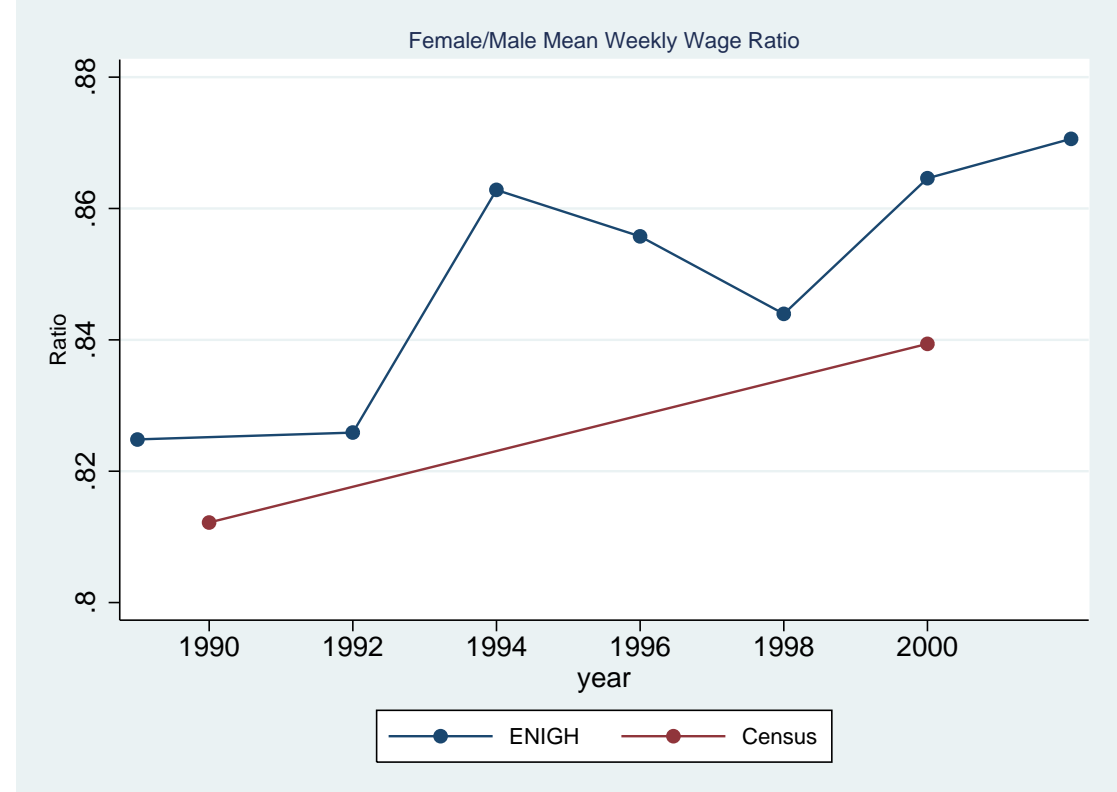

Figure 2: Female-Male Weekly Wage Ratio. Source: Aguayo, Airola, Juhn, and Villegas-Sanchez (2011). The figure is based on Household Income and Expenditure Surveys (ENIGH) and the 1990 and 2000 Mexican Population Census. The wage sample consists of men and women who are 15-64 years old, who reported working full-time (30 hours or more), and who either did not have self-employment earnings or reported that they were not self-employed. We also winsorize the top and bottom 1 percent of observations by gender. 


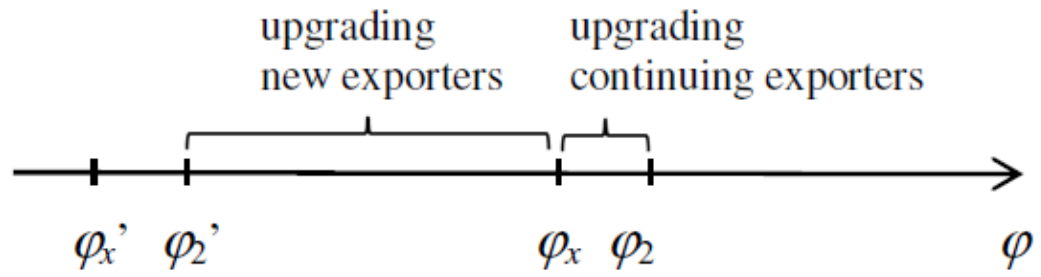

(a)

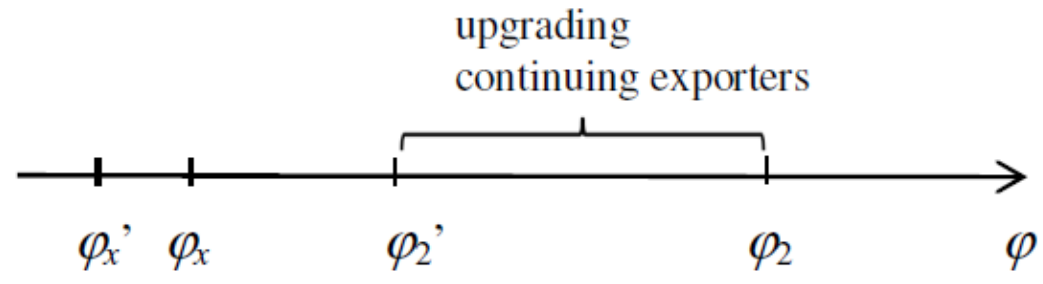

(b)

Figure 3: Technology upgrading among new and continuing exporters. Notation: Primed thresholds represent the values after trade liberalization. In panel (a), technology upgrading occurs mainly among new exporters. In panel (b), it occurs exclusively among continuing exporters. 


\section{Appendix A Proofs}

Proof of proposition 1.

Proof. Using (3) we can define the cutoffs $\varphi_{x}^{*}$ and $\varphi_{2}^{*}$ as, respectively $\pi_{1}\left(W, P, \varphi_{x}^{*}, 0\right)=\pi_{1}\left(W, P, \varphi_{x}^{*}, 1\right)$ and $\pi_{1}\left(W, P, \varphi_{2}^{*}, 1\right)=\pi_{2}\left(W, P, \varphi_{2}^{*}, 1\right)$. In addition, the exit cutoff $\varphi_{1}^{*}$ is defined by $\pi_{1}\left(W, P, \varphi_{1}^{*}, 0\right)=$ 0 . It is convenient to express the first two of these as a function of the third one. Some algebra gives

$$
\begin{aligned}
\varphi_{x}^{*} & =\varphi_{1}^{*} \tau\left(f_{x} / f_{1}\right)^{\frac{1}{\sigma-1}} \\
\varphi_{2}^{*} & =\varphi_{1}^{*}\left[\frac{\frac{f_{2}}{f_{1}}-1}{\left(1+\tau^{1-\sigma}\right)\left(\lambda^{\sigma-1}-1\right)}\right]^{\frac{1}{\sigma-1}},
\end{aligned}
$$

where $\lambda=\frac{\gamma \kappa_{2}}{\kappa_{1}}\left(\frac{W_{b m}}{W_{b f}}\right)^{\alpha_{1}\left(1-\beta_{1}\right)-\alpha_{2}\left(1-\beta_{2}\right)}\left(\frac{W_{w f}}{W_{b f}}\right)^{\alpha_{2}-\alpha_{1}}\left(\frac{W_{w m}}{W_{w f}}\right)^{\left(1-\alpha_{1}\right)\left(1-\varpi_{1}\right)-\left(1-\alpha_{2}\right)\left(1-\varpi_{2}\right)}$. These cutoffs are identical to those in Bustos (2011b, p18-19), except for the definition of $\lambda$ and $\varphi_{1}^{*}$. This implies that the expression for the relative total revenue $\frac{R_{1}}{R_{2}}$ is also identical to hers once $\lambda$ and $\varphi_{1}^{*}$ are defined appropriately (p20):

$$
\frac{R_{1}}{R_{2}}=\frac{1}{\lambda^{\sigma-1}\left(1+\tau^{1-\sigma}\right)}\left\{\left[\frac{\varphi_{2}^{*}}{\varphi_{1}^{*}}\right]^{k-\sigma+1}-1+\tau^{1-\sigma}\left[\frac{\varphi_{2}^{*}}{\varphi_{x}^{*}}\right]^{k-\sigma+1}-\tau^{1-\sigma}\right\} .
$$

But since under (A-18) and (A-19) this expression does not depend on $\varphi_{1}^{*}, \frac{R_{1}}{R_{2}}$ only depends on $W$ through $\lambda$.

Given (A-18) and (A-19), parts (i) and (ii) of the Proposition follow directly from Bustos's (2011b) Proposition 1(e). Proposition 1(b) in Bustos (2011b) implies that $\frac{\partial\left(R_{1} / R_{2}\right)}{\partial \tau}>0$. Since $\beta_{2}>\beta_{1}$, it follows from (8) that $\frac{\partial\left(W_{b f} / W_{b m}\right)}{\partial \tau}<0$ as stated in part (iii). This result together with (1) implies that firms that do not change their technology after trade liberalization will have a lower relative demand for blue-collar female workers. Therefore, as stated in part (iv), firms switching technology must increase their demand for these workers or else (iii) could not hold.

\section{Proof of proposition 2 .}

Proof. Part (i) follows directly from (10). To see part (ii), use (1) and (2) to write the relative 
wage paid by a firm using technology $t$ as

$$
\frac{\frac{W_{w f} L_{w f}+W_{w m} L_{w m}}{L_{w f}+L_{w m}}}{\frac{W_{b f} L_{b f}+W_{b m} L_{b m}}{L_{b f}+L_{b m}}}=\frac{W_{w f}}{W_{b f}} \frac{\frac{\varpi}{1-\varpi}+1}{\frac{\varpi}{1-\varpi}+\frac{W_{w f}}{W_{w m}}} \frac{\frac{\beta_{t}}{1-\beta_{t}}+\frac{W_{b f}}{W_{b m}}}{\frac{\beta_{t}}{1-\beta_{t}}+1} .
$$

Using (8)-(10) together with the result that $\frac{\partial\left(R_{1} / R_{2}\right)}{\partial \tau}>0$ (see Proposition 1), one can show that the derivative of this expression with respect to $\tau$ is proportional to the expression in the Proposition. Note that the condition can be satisfied because $\alpha_{1}>\alpha_{2}$.

\section{Appendix B Data and Cleaning Procedure}

\section{Appendix B.1 Variable Description}

-Output: Manufacturing plants: Value of production priced at "factory price"(ENESTyC). - Labor: Average number of workers (ENESTyC). - Materials: Expenditure in materials (ENESTyC) Capital: Value of Total Assets (ENESTyC). - Foreign: Dummy equal 1 if the capital owned by foreign investors is more than 10\% (ENESTyC). -Exporter: Dummy equal 1 if firm sells to foreign markets (ENESTyC).

\section{Appendix B.2 Cleaning Procedure}

The following establishments were removed:

1. Establishments that report zero or missing values for Output, Materials, Average employment and/or Total Assets. This means removing a total of 216 firm in 1992 and 640 in 2001.

2. Establishments fully or partially owned by the government.

3. In order to make more comparable the surveyed samples in 1992 and 2001, we remove establishments in sector 3511 "Basic Petrochemicals" and sector 3530 "Oil refinery" because these sectors were only included in the 2001 survey.

4. In addition, the main variables are winsorized at the tails. The key variables are the real value of output, the real value of materials expenditure, the real value of total assets and the average number of workers. We replace values in the lower and upper $1 \%$ tails with values at the 1 st and 99th percentiles, respectively. 


\section{Appendix B.3 Price Index}

Ideally, for output, materials and capital we would need data on physical quantities rather than values. Unfortunately this data is not available in the ENESTyC survey hence, in order to approximate quantities and express all monetary variables in real terms we use industry wide price index deflators.

- Output: We express the value of production priced at the "factory" price (venta de fabrica) in pesos of 2003 using producer price index (PPI) data breakdown by industry, facilitated by the Central Bank of Mexico. The Central Bank of Mexico uses a different industry classification (CMAE, Clasificacion Mexicana de Actividades Mexicanas) than the one used in the ENESTyC (CMAP). We use a table of correspondence between CMAE and CMAP provided by INEGI and a PPI deflator at the branch level. In order to obtain the PPI at the branch level, for each branch we take the average over the corresponding classes belonging to that branch.

- Exports: There is no export price deflator breakdown by industry readily available so we follow Lach, Roberts and Tybout (1998) and Fernandes and Isgut (2005) in the construction of export price indexes. As in Lach et at (1998) we use data from the United Nations COMTRADE database on the values and quantities of manufactured exports from Mexico to the rest of the world by product category, and we conduct the following exercise. First, we develop a correspondence between the UN ISIC Rev3 classification and the Mexican CMAP branch classification by careful examination of the product descriptions in each system. Second, we compute unit export values for each ISIC category by dividing the trade value figures by the trade quantity figures. These unit export values are expressed in current US dollars so we convert them into unit values in pesos using the average nominal ER between peso and dollar. Third, following Fernandes and Isgut (2005) we regress the $\log$ of the unit export price on 2-digit sector dummies, year dummies and year-sector fixed effects. The estimation is done by weighted least squares, with weights corresponding to the square root of the share of each product category trade value in the total 2-digit sector trade value. From this regression we obtain predicted log unit export prices for each UN ISIC Rev3 category. Finally, using the previous weights and the correspondence between the ISIC classification and the CMAP classification we compute a weighted average of the predicted unit values belonging to the same 
2-digit sector CMAP classification. We normalize the export price series for each industry to the same base year as the domestic producer price index.

- Materials: We express the expenditure in materials in pesos of 2003 using a materials price index (MPI) provided by the Central Bank of Mexico. In particular, we use the MPI according to which sector consumes those materials. Again, the industry classification of the Central Bank of Mexico is the CMAE and we use the same previous table of correspondence between CMAE and CMAP to obtain the CMAP figures at the branch level. Although this price index might be relevant for plants that buy their materials domestically it might as well be misleading in the case of plants that import most of their raw materials. To avoid such a bias, we use different price indexes for the expenditure in materials paid at home and the expenditure in imported materials. To obtain a price index for imports at the CMAP branch level we follow the same procedure as for the export price index, this time using Mexican imports from the rest of the world by product category.

- Capital: We use the PPI to deflate the value of total assets.

\section{Appendix C Appendix Tables}


Table B1: Summary Statistics

\begin{tabular}{|c|c|c|c|c|c|c|}
\hline \multicolumn{7}{|c|}{ Panel A: Cross-Section of Firms } \\
\hline & & 1991 & & & 2000 & \\
\hline & Obs & Average & Sd. & Obs & Average & Sd. \\
\hline \multicolumn{7}{|l|}{ Firm Characteristics } \\
\hline $\ln (K / V A)$ & 3905 & -0.34 & 1.40 & 5095 & -0.50 & 1.67 \\
\hline $\ln (V A)$ & 3905 & 10.67 & 1.68 & 5095 & 10.37 & 1.94 \\
\hline $\ln (K)$ & 3991 & 10.33 & 2.02 & 5466 & 9.88 & 2.08 \\
\hline Employment & 3991 & 365.49 & 685.99 & 5466 & 406.22 & 872.44 \\
\hline Share $R \& D$ & 3991 & 7.67 & 18.08 & & & \\
\hline Foreign & 3991 & 0.22 & 0.42 & 4861 & 0.25 & 0.43 \\
\hline Exporter & 3991 & 0.32 & 0.47 & 5459 & 0.56 & 0.50 \\
\hline ExportShare & 3991 & 17.94 & 34.31 & 5387 & 21.76 & 34.05 \\
\hline Employment : WhitetoBlueRatio & 3991 & 0.62 & 2.59 & 5466 & 0.62 & 1.70 \\
\hline \multicolumn{7}{|l|}{ Female-Male Labor Ratios } \\
\hline \multicolumn{7}{|l|}{ White Collar } \\
\hline Employment : FemaletoMaleRatio & 3967 & 0.44 & 0.64 & 5407 & 0.60 & 0.81 \\
\hline WageBill : FemaletoMaleRatio & 3963 & 0.30 & 0.44 & 5364 & 0.44 & 0.70 \\
\hline Wage: FemaletoMaleRatio & 3793 & 0.71 & 0.37 & 5201 & 0.82 & 0.54 \\
\hline \multicolumn{7}{|l|}{ Blue Collar } \\
\hline Employment : FemaletoMaleRatio & 3991 & 0.62 & 1.09 & 5466 & 0.66 & 0.99 \\
\hline WageBill : FemaletoMaleRatio & 3991 & 0.57 & 1.06 & 5466 & 0.60 & 0.96 \\
\hline Wage: FemaletoMaleRatio & 2707 & 0.90 & 0.34 & 4106 & 0.94 & 0.32 \\
\hline \multicolumn{7}{|l|}{ Technology } \\
\hline ValueMachineryEquipment & 3991 & 28786.41 & 141814 & 5465 & 93101.89 & 649522.7 \\
\hline ComputerizedMachinery & & & & 5466 & 0.52 & 0.50 \\
\hline NewMachinery & & & & 5466 & 0.65 & 0.48 \\
\hline ImportedMachinery & & & & 5466 & 0.53 & 0.50 \\
\hline UpgradedMachinery & & & & 5466 & 0.29 & 0.45 \\
\hline ValueUpgradedMachinery & & & & 5465 & 45930.62 & 524398.4 \\
\hline ValueNON-UpgradedMachinery & & & & 5465 & 43538.95 & 386385.1 \\
\hline \multicolumn{7}{|c|}{ Panel B: Panel of Firms } \\
\hline & & 1991 & & & 2000 & \\
\hline & Obs & Average & $\mathrm{Sd}$. & Obs & Average & $\mathrm{Sd}$. \\
\hline \multicolumn{7}{|l|}{ Firm Characteristics } \\
\hline $\ln (K / V A)$ & 922 & -0.30 & $\begin{array}{l}1.31 \\
1.34\end{array}$ & 873 & -0.08 & 1.39 \\
\hline $\begin{array}{l}\ln (V A) \\
\ln (K)\end{array}$ & $\begin{array}{l}922 \\
938\end{array}$ & $\begin{array}{l}11.34 \\
11.04\end{array}$ & $\begin{array}{l}1.34 \\
1.69\end{array}$ & $\begin{array}{l}873 \\
938\end{array}$ & $\begin{array}{l}11.04 \\
10.94\end{array}$ & $\begin{array}{l}1.50 \\
1.70\end{array}$ \\
\hline $\begin{array}{l}\ln (K) \\
\text { Employment }\end{array}$ & $\begin{array}{l}938 \\
938\end{array}$ & 422.31 & $\begin{array}{l}1.09 \\
510.42\end{array}$ & 938 & 441.65 & 517.87 \\
\hline Share $R \& D$ & 938 & 7.51 & 16.56 & & & \\
\hline Foreign & 938 & 0.18 & 0.38 & 823 & 0.20 & 0.40 \\
\hline Exporter & 938 & 0.38 & 0.49 & 938 & 0.57 & 0.49 \\
\hline ExportShare & 938 & 8.42 & 20.46 & 938 & 13.92 & 22.99 \\
\hline Employment: WhitetoBlueRatio & 936 & 0.52 & 0.60 & 935 & 0.70 & 1.15 \\
\hline \multicolumn{7}{|l|}{ Female-Male Labor Ratios } \\
\hline \multicolumn{7}{|l|}{ White Collar } \\
\hline Employment: FemaletoMaleRatio & 937 & 0.39 & 0.46 & 934 & 0.43 & 0.58 \\
\hline WageBill : FemaletoMaleRatio & 937 & 0.26 & 0.32 & 933 & 0.32 & 0.42 \\
\hline Wage: FemaletoMaleRatio & 908 & 0.70 & 0.32 & 921 & 0.82 & 0.41 \\
\hline \multicolumn{7}{|l|}{ Blue Collar } \\
\hline Employment : FemaletoMaleRatio & 934 & 0.64 & 1.96 & 933 & 0.66 & 2.20 \\
\hline WageBill : FemaletoMaleRatio & 934 & 0.54 & 1.55 & 933 & 0.64 & 2.35 \\
\hline Wage: FemaletoMaleRatio & 653 & 0.91 & 0.48 & 670 & 0.94 & 0.30 \\
\hline \multicolumn{7}{|l|}{ Technology } \\
\hline ValueMachineryEquipment & 937 & 38987.91 & 163054.9 & 936 & 146187.8 & 528044.6 \\
\hline ComputerizedMachinery & & & & 938 & 0.61 & 0.49 \\
\hline NewMachinery & & & & 938 & 0.69 & 0.46 \\
\hline ImportedMachinery & & & & 938 & 0.53 & 0.50 \\
\hline UpgradedMachinery & & & & 938 & 0.35 & 0.48 \\
\hline ValueUparadedMachinery & & & & 936 & 79641.83 & 491033.1 \\
\hline ValueNON - UpgradedMachinery & & & & 936 & 61915.08 & 216592.1 \\
\hline \multicolumn{7}{|l|}{ Export Status } \\
\hline ContinuingExporters & & & & 938 & 0.34 & 0.47 \\
\hline NewExporters & & & & 938 & 0.24 & 0.43 \\
\hline StopExporters & & & & 938 & 0.06 & 0.24 \\
\hline
\end{tabular}

Notes: $\ln (K / V A)$ is the $\log$ of total assets to value added. $\ln (V A)$ is the $\log$ of value added. Share $R \& D$ is the share of $\mathrm{R} \& \mathrm{D}$ spending in total income. $\ln (K)$ is the log of total assets. Employment is the total number of employees. Foreign is a dummy variable that takes the value of one if the firm was more than 10 percent owned by foreign-owned investors and zero otherwise. Exporter is a dummy that equals one if the firm reported sales revenue abroad and zero otherwise. ExportShare is the share of export revenue in total sales. Employment : WhitetoBlueRatio is the ratio of white collar number of employees to blue collar number of employees. White collar includes the categories: Directors and Managers while Blue Collar refers to Specialized Workers and General Workers. The wage is computed as the ratio of Wage Bill to Employment. ValueMachineryEquipment refers to the deflated value of Machinery and Equipment. ComputerizedMachinery equals one if the machinery and equipment acquired since 1999 was automatic/computerized (as opposed to manual or involving machinery tools). NewMachinery equals one if the machinery and equipment acquired since 1999 is new (as opposed to used). ImportedMachinery equals one if the machinery and equipment acquired since 1999 is imported from developed countries. UpgradedMachinery equals one if the machinery and equipment acquired since 1999 is computerized, new and imported from developed countries. Non-UpgradedMachinery equals one if the machinery and equipment acquired since 1999 is neither computerized, nor new nor imported from developed countries. ContinuingExporters are those firms that exported in 1991 and 2000. NewExporters are those firms that did not export in 1991 but export in 2000. StopExporters are firms that exported in 1991 but do not export in 2000. The omitted category is Non - Exporter. 
Table B2: Characteristics of Exporters relative to Non-Exporters

\begin{tabular}{|c|c|c|c|c|c|c|c|c|c|c|}
\hline \multirow[b]{3}{*}{ Employment } & \multicolumn{5}{|c|}{ Levels in 1991} & \multicolumn{4}{|c|}{ Log Changes 1991-2000 } & \multirow[b]{2}{*}{ Obs. } \\
\hline & \multicolumn{2}{|c|}{$\begin{array}{l}\text { Continuing } \\
\text { Exporter }\end{array}$} & \multicolumn{2}{|c|}{$\begin{array}{l}\text { New } \\
\text { Exporter }\end{array}$} & \multirow{2}{*}{$\begin{array}{l}\text { Obs. } \\
938\end{array}$} & \multicolumn{2}{|c|}{$\begin{array}{l}\text { Continuing } \\
\text { Exporter }\end{array}$} & \multicolumn{2}{|l|}{$\begin{array}{l}\text { New } \\
\text { Exporter }\end{array}$} & \\
\hline & $0.444^{* * *}$ & $(0.067)$ & $0.206^{* *}$ & $(0.064)$ & & -0.016 & $(0.044)$ & 0.006 & $(0.047)$ & 938 \\
\hline Sales & $0.734^{* * *}$ & $(0.096)$ & $0.288^{* *}$ & $(0.093)$ & 938 & $0.157^{* *}$ & $(0.066)$ & $0.227^{* * *}$ & $(0.067)$ & 938 \\
\hline Value Added per Employee & $0.219^{* *}$ & $(0.083)$ & 0.021 & $(0.086)$ & 922 & 0.127 & $(0.102)$ & $0.213^{* *}$ & $(0.103)$ & 858 \\
\hline Capital to Labor ratio & $0.755^{* * *}$ & $(0.109)$ & $0.200^{*}$ & $(0.120)$ & 938 & -0.100 & $(0.125)$ & 0.198 & $(0.130)$ & 938 \\
\hline Skill intensity & $0.117^{* *}$ & $(0.045)$ & -0.033 & $(0.045)$ & 937 & -0.040 & $(0.054)$ & -0.022 & $(0.054)$ & 933 \\
\hline Wage & $0.152^{* * *}$ & $(0.030)$ & $0.052^{*}$ & $(0.030)$ & 938 & $0.097^{* *}$ & $(0.037)$ & 0.060 & $(0.038)$ & 938 \\
\hline White Wage & $0.130^{* * *}$ & $(0.034)$ & 0.035 & $(0.036)$ & 937 & $0.155^{* * *}$ & $(0.045)$ & $0.136^{* *}$ & $(0.049)$ & 932 \\
\hline
\end{tabular}

Notes: Robust standard errors in parenthesis. Exporter premia are estimated from a regression of the form: $\ln \left(Y_{i, s^{\prime}}\right)=$

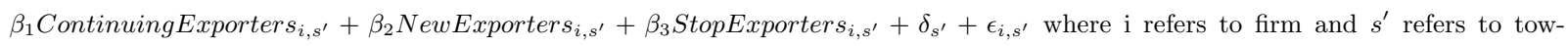
digit industry classification. ContinuingExporters are firms that exported in 1991 and 2000, NewExporters are firms that did not export in 1991 but do export in 2000 and StopExporters are firms that exported in 1991 and do not export in 2000. The reference category is Non - Exporters which are firms that never exported. 
Table B3: Employer Preference in Hiring by Occupational Category and Foreign Ownership Status

\begin{tabular}{|c|c|c|c|c|c|}
\hline \multicolumn{6}{|c|}{ Panel A: Directors } \\
\hline & \multicolumn{2}{|c|}{ Domestic } & & \multicolumn{2}{|c|}{ Foreign } \\
\hline & Observ. & Percent & & Observ. & Percent \\
\hline Male & 144 & 25.49 & Male & 36 & 23.68 \\
\hline Female & 3 & 0.53 & Female & 1 & 0.66 \\
\hline Indifferent & 418 & 73.98 & Indifferent & 115 & 75.66 \\
\hline Total & 565 & 100 & Total & 152 & 100 \\
\hline
\end{tabular}

Panel B: Managers

\begin{tabular}{|c|c|c|c|c|c|}
\hline & \multicolumn{2}{|c|}{ Domestic } & & \multicolumn{2}{|c|}{ Foreign } \\
\hline & Observ. & Percent & & Observ. & Percent \\
\hline Male & 27 & 4.17 & Male & 5 & 3.11 \\
\hline Female & 25 & 3.86 & Female & 9 & 5.59 \\
\hline Indifferent & 596 & 91.98 & Indifferent & 147 & 91.3 \\
\hline Total & 648 & 100 & Total & 161 & 100 \\
\hline
\end{tabular}

Panel C: Specialized Workers

\begin{tabular}{|c|c|c|c|c|c|}
\hline & \multicolumn{2}{|c|}{ Domestic } & & \multicolumn{2}{|c|}{ Foreign } \\
\hline & Observ. & Percent & & Observ. & Percent \\
\hline Male & 338 & 54.52 & Male & 82 & 53.25 \\
\hline Female & 21 & 3.39 & Female & 1 & 0.65 \\
\hline Indifferent & 261 & 42.1 & Indifferent & 71 & 46.1 \\
\hline Total & 620 & 100 & Total & 154 & 100 \\
\hline \multicolumn{6}{|c|}{ Panel D: General Workers } \\
\hline & \multicolumn{2}{|c|}{ Domestic } & & \multicolumn{2}{|c|}{ Foreign } \\
\hline & Observ. & Percent & & Observ. & Percent \\
\hline Male & 288 & 44.44 & Male & 71 & 47.02 \\
\hline Female & 35 & 5.4 & Female & 3 & 1.99 \\
\hline Indifferent & 325 & 50.15 & Indifferent & 77 & 50.99 \\
\hline Total & 648 & 100 & Total & 151 & 100 \\
\hline
\end{tabular}




\section{Table B4: Alternative Channel: Education}

\begin{tabular}{|c|c|c|c|c|c|c|}
\hline & \multicolumn{6}{|c|}{ Dependent variable: Growth in Female-Male Labor Ratios } \\
\hline & \multicolumn{3}{|c|}{ White Collar } & \multicolumn{3}{|c|}{ Blue Collar } \\
\hline & $\begin{array}{c}\text { Female-Male } \\
\text { Employment } \\
\text { Growth } \\
(1) \\
\end{array}$ & $\begin{array}{c}\text { Female-Male } \\
\text { Wage Bill } \\
\text { Growth } \\
(2)\end{array}$ & $\begin{array}{c}\text { Female-Male } \\
\text { Wage } \\
\text { Growth } \\
(3) \\
\end{array}$ & $\begin{array}{c}\text { Female-Male } \\
\text { Employment } \\
\text { Growth } \\
(4) \\
\end{array}$ & $\begin{array}{c}\text { Female-Male } \\
\text { Wage Bill } \\
\text { Growth } \\
(5)\end{array}$ & $\begin{array}{c}\text { Female-Male } \\
\text { Wage } \\
\text { Growth } \\
(6) \\
\end{array}$ \\
\hline$\Delta$ Export Tariff & $\begin{array}{c}0.023 \\
(0.026)\end{array}$ & $\begin{array}{c}0.016 \\
(0.024)\end{array}$ & $\begin{array}{l}-0.009 \\
(0.007)\end{array}$ & $\begin{array}{l}-0.027 \\
(0.023)\end{array}$ & $\begin{array}{l}-0.035 \\
(0.022)\end{array}$ & $\begin{array}{c}-0.012^{* *} \\
(0.006)\end{array}$ \\
\hline RegionalSchooling & $\begin{array}{c}5.450 \\
(3.646)\end{array}$ & $\begin{array}{l}6.939^{*} \\
(3.706)\end{array}$ & $\begin{array}{c}0.882 \\
(1.804)\end{array}$ & $\begin{array}{c}20.811^{* * *} \\
(6.168)\end{array}$ & $\begin{array}{c}18.718^{* *} \\
(6.566)\end{array}$ & $\begin{array}{l}-1.998 \\
(1.781)\end{array}$ \\
\hline $\ln (K / V A)_{\text {init }}$ & $\begin{array}{c}0.030 \\
(0.040)\end{array}$ & $\begin{array}{c}0.026 \\
(0.039)\end{array}$ & $\begin{array}{l}-0.014 \\
(0.015)\end{array}$ & $\begin{array}{c}0.018 \\
(0.046)\end{array}$ & $\begin{array}{c}0.031 \\
(0.048)\end{array}$ & $\begin{array}{c}0.007 \\
(0.015)\end{array}$ \\
\hline $\ln (V A)_{\text {init }}$ & $\begin{array}{l}-0.027 \\
(0.041)\end{array}$ & $\begin{array}{l}-0.023 \\
(0.039)\end{array}$ & $\begin{array}{l}-0.004 \\
(0.017)\end{array}$ & $\begin{array}{l}-0.051 \\
(0.051)\end{array}$ & $\begin{array}{l}-0.054 \\
(0.052)\end{array}$ & $\begin{array}{l}-0.008 \\
(0.013)\end{array}$ \\
\hline R\&Dshare ${ }_{\text {init }}$ & $\begin{array}{c}0.009^{* *} \\
(0.003)\end{array}$ & $\begin{array}{c}0.007^{* *} \\
(0.003)\end{array}$ & $\begin{array}{l}-0.001 \\
(0.001)\end{array}$ & $\begin{array}{l}-0.002 \\
(0.004)\end{array}$ & $\begin{array}{l}-0.001 \\
(0.004)\end{array}$ & $\begin{array}{c}0.001 \\
(0.001)\end{array}$ \\
\hline Foreign $_{\text {init }}$ & $\begin{array}{l}-0.000 \\
(0.116)\end{array}$ & $\begin{array}{l}-0.002 \\
(0.114)\end{array}$ & $\begin{array}{c}0.011 \\
(0.063)\end{array}$ & $\begin{array}{l}-0.038 \\
(0.161)\end{array}$ & $\begin{array}{l}-0.005 \\
(0.165)\end{array}$ & $\begin{array}{c}0.031 \\
(0.051)\end{array}$ \\
\hline $\begin{array}{l}\text { Observations } \\
\mathrm{R}^{2} \\
\text { Sector2dig Fixed Effects }\end{array}$ & $\begin{array}{l}899 \\
.028 \\
\text { Yes }\end{array}$ & $\begin{array}{l}898 \\
.025 \\
\text { Yes }\end{array}$ & $\begin{array}{l}862 \\
.019 \\
\text { Yes }\end{array}$ & $\begin{array}{l}895 \\
.027 \\
\text { Yes }\end{array}$ & $\begin{array}{l}895 \\
.026 \\
\text { Yes }\end{array}$ & $\begin{array}{l}562 \\
.024 \\
\text { Yes }\end{array}$ \\
\hline
\end{tabular}

Notes: Standard errors clustered at cmap level in parentheses. $\Delta$ Export Tariff indicates the change in sectoral tariffs (6-digit sector classification) applied by the US between 2000 and 1991. RegionalSchooling refers to the growth rate between 1991 and 2000 in the ratio of female to male average education by Federal State (there are 32 Federal States). Columns (1) to (3) refer to the White-Collar category while columns (4) to (6) refer to the Blue-Collar category. Female-Male Employment growth refers to the growth in female to male employment ratios between 1991 and 2000. Female-Male Wage Bill is the growth in female to male wage bill ratios between 1991 and 2000. Female-Male wage is the growth in female to male wage ratios between 1991 and 2000. The wage is computed as the ratio of Wage Bill to Employment. The growth rate is computed as $\ln (($ female - maleratio $)+0.001)-\ln ((\text { female }- \text { maleratio })+0.001)_{t-1} \cdot \ln (K / V A)_{\text {init }}$ is the $\log$ of total assets to value added in 1991. $\ln (K / V A)_{\text {init }}$ is the $\log$ of total assets to value added in 1991. $\ln (V A)_{\text {init }}$ is the log value added in 1991. R\&Dshare init $_{\text {it }}$ is the share of R\&D spending in total income in 1991. Foreign init $_{\text {is }}$ a dummy variable that takes the value of one if the firm was more than 10 percent owned by foreign-owned investors in 1991 and zero otherwise. ${ }^{* * *},{ }^{* *},{ }^{*}$, denote significance at $1 \%$, $5 \%, 10 \%$ levels. 


\section{Table B5: Technology Upgrading and Female-Male Labor Outcomes (IV)}

\begin{tabular}{|c|c|c|c|c|c|c|c|c|c|}
\hline & & & Dependent & ble: Growth in & male-Male Lab & Ratios in the & Collar Categor & & \\
\hline & $\begin{array}{c}\text { Female-Male } \\
\text { Employment } \\
\text { Growth } \\
(1)\end{array}$ & $\begin{array}{l}\text { Female-Male } \\
\text { Wage Bill } \\
\text { Growth } \\
(2)\end{array}$ & $\begin{array}{c}\text { Female-Male } \\
\text { Wage } \\
\text { Growth } \\
(3)\end{array}$ & $\begin{array}{c}\text { Female-Male } \\
\text { Employment } \\
\text { Growth } \\
(4)\end{array}$ & $\begin{array}{l}\text { Female-Male } \\
\text { Wage Bill } \\
\text { Growth } \\
(5)\end{array}$ & $\begin{array}{c}\text { Female-Male } \\
\text { Wage } \\
\text { Growth } \\
(6)\end{array}$ & $\begin{array}{c}\text { Female-Male } \\
\text { Employment } \\
\text { Growth } \\
(7) \\
\end{array}$ & $\begin{array}{c}\text { Female-Male } \\
\text { Wage Bill } \\
\text { Growth } \\
(8)\end{array}$ & $\begin{array}{c}\text { Female-Male } \\
\text { Wage } \\
\text { Growth } \\
(9) \\
\end{array}$ \\
\hline Machinery Growth & $\begin{array}{c}0.543 \\
(0.443)\end{array}$ & $\begin{array}{c}0.635 \\
(0.457)\end{array}$ & $\begin{array}{c}0.203 \\
(0.213)\end{array}$ & & & & & & \\
\hline Upgraded Machinery Growth & & & & $\begin{array}{l}0.652^{*} \\
(0.395)\end{array}$ & $\begin{array}{l}0.763^{*} \\
(0.392)\end{array}$ & $\begin{array}{c}0.242 \\
(0.157)\end{array}$ & & & \\
\hline Non-Upgraded Machinery Growth & & & & & & & $\begin{array}{c}3.206 \\
(7.529)\end{array}$ & $\begin{array}{c}3.753 \\
(8.537)\end{array}$ & $\begin{array}{c}0.907 \\
(2.775)\end{array}$ \\
\hline $\ln (K / V A)_{\text {init }}$ & $\begin{array}{c}0.297 \\
(0.246)\end{array}$ & $\begin{array}{c}0.362 \\
(0.254)\end{array}$ & $\begin{array}{c}0.123 \\
(0.124)\end{array}$ & $\begin{array}{c}0.117 \\
(0.081)\end{array}$ & $\begin{array}{l}0.150^{*} \\
(0.079)\end{array}$ & $\begin{array}{l}0.049^{*} \\
(0.028)\end{array}$ & $\begin{array}{c}1.122 \\
(2.658)\end{array}$ & $\begin{array}{c}1.327 \\
(3.016)\end{array}$ & $\begin{array}{c}0.354 \\
(1.077)\end{array}$ \\
\hline $\ln (V A)_{\text {init }}$ & $\begin{array}{c}0.056 \\
(0.089)\end{array}$ & $\begin{array}{c}0.073 \\
(0.088)\end{array}$ & $\begin{array}{c}0.041 \\
(0.048)\end{array}$ & $\begin{array}{c}-0.020 \\
(0.051)\end{array}$ & $\begin{array}{c}-0.016 \\
(0.052)\end{array}$ & $\begin{array}{c}0.008 \\
(0.017)\end{array}$ & $\begin{array}{c}0.368 \\
(0.966)\end{array}$ & $\begin{array}{c}0.437 \\
(1.094)\end{array}$ & $\begin{array}{c}0.134 \\
(0.430)\end{array}$ \\
\hline$R \& D$ share $_{\text {init }}$ & $\begin{array}{c}0.000 \\
(0.005)\end{array}$ & $\begin{array}{c}0.001 \\
(0.005)\end{array}$ & $\begin{array}{c}0.001 \\
(0.001)\end{array}$ & $\begin{array}{c}0.000 \\
(0.005)\end{array}$ & $\begin{array}{c}0.001 \\
(0.005)\end{array}$ & $\begin{array}{c}0.001 \\
(0.001)\end{array}$ & $\begin{array}{c}-0.001 \\
(0.008)\end{array}$ & $\begin{array}{c}-0.001 \\
(0.009)\end{array}$ & $\begin{array}{c}0.003 \\
(0.007)\end{array}$ \\
\hline Foreign $_{\text {init }}$ & $\begin{array}{c}-0.241 \\
(0.217)\end{array}$ & $\begin{array}{c}-0.243 \\
(0.224)\end{array}$ & $\begin{array}{c}-0.032 \\
(0.086)\end{array}$ & $\begin{array}{c}-0.130 \\
(0.174)\end{array}$ & $\begin{array}{c}-0.113 \\
(0.181)\end{array}$ & $\begin{array}{c}-0.001 \\
(0.064)\end{array}$ & $\begin{array}{c}-0.695 \\
(1.555)\end{array}$ & $\begin{array}{c}-0.775 \\
(1.762)\end{array}$ & $\begin{array}{c}-0.088 \\
(0.378)\end{array}$ \\
\hline Observations & 895 & 895 & 562 & 895 & 895 & 562 & 895 & 895 & 562 \\
\hline Sector2dig Fixed Effects & Yes & Yes & Yes & Yes & Yes & Yes & Yes & Yes & Yes \\
\hline
\end{tabular}

Dependent variable: Growth Value of Machinery

\begin{tabular}{|c|c|c|c|c|c|c|c|c|c|}
\hline & $\begin{array}{c}\text { Machinery } \\
\text { Value Growth } \\
(1)\end{array}$ & $\begin{array}{c}\text { Machinery } \\
\text { Value Growth } \\
(2)\end{array}$ & $\begin{array}{c}\text { Machinery } \\
\text { Value Growth } \\
(3)\end{array}$ & $\begin{array}{c}\text { Upgraded } \\
\text { Machinery } \\
\text { Value Growth } \\
(4)\end{array}$ & $\begin{array}{c}\text { Upgraded } \\
\text { Machinery } \\
\text { Value Growth } \\
(5)\end{array}$ & $\begin{array}{c}\text { Upgraded } \\
\text { Machinery } \\
\text { Value Growth } \\
(6)\end{array}$ & $\begin{array}{l}\text { Non-Upgraded } \\
\text { Machinery } \\
\text { Value Growth } \\
(7)\end{array}$ & $\begin{array}{l}\text { Non-Upgraded } \\
\text { Machinery } \\
\text { Value Growth } \\
(8)\end{array}$ & $\begin{array}{c}\text { Non-Upgraded } \\
\text { Machinery } \\
\text { Value Growth } \\
(9)\end{array}$ \\
\hline$\Delta$ Export Tariff & $\begin{array}{c}-0.073^{* *} \\
(0.035)\end{array}$ & $\begin{array}{c}-0.073^{* *} \\
(0.035)\end{array}$ & $\begin{array}{l}-0.051 \\
(0.051)\end{array}$ & $\begin{array}{c}-0.061^{* * *} \\
(0.012)\end{array}$ & $\begin{array}{c}-0.061^{* * * *} \\
(0.012)\end{array}$ & $\begin{array}{c}-0.043^{* *} \\
(0.017)\end{array}$ & $\begin{array}{l}-0.012 \\
(0.027)\end{array}$ & $\begin{array}{l}-0.012 \\
(0.027)\end{array}$ & $\begin{array}{l}-0.011 \\
(0.036)\end{array}$ \\
\hline Observations & 895 & 895 & 562 & 895 & 895 & 562 & 895 & 895 & 562 \\
\hline \multicolumn{10}{|l|}{ Tests } \\
\hline F-Test & 4.45 & 4.45 & 1 & 26.37 & 26.37 & 6.56 & 1.49 & 1.49 & 0.58 \\
\hline Anderson & 3.24 & 4.72 & 3.6 & 3.24 & 4.72 & 3.6 & 3.24 & 4.72 & 3.6 \\
\hline Cragg-Donald & 4.454 & 4.454 & 1 & 26.375 & 26.375 & 6.564 & 1.493 & 1.493 & 0.583 \\
\hline
\end{tabular}

Notes:Standard errors clustered at cmap level in parentheses. Panel A reports the results from the Second Stage. Panel B reports the results from the First Stage. $\Delta$ Export Tariff indicates the change in sectoral tariffs (6-digit sector classification) applied by the US between 2000 and 1991. Upgraded Machinery Growth refers to the product of the log difference in the value of machinery and equipment between 2000 and 1991 and a dummy variable that equals one if the machinery and equipment acquired since 1999 is automatic/computerized and it is new machinery imported from developed countries. The Non-Upgraded Machinery equals one if the machinery and equipment acquired since 1999 is not automatic/computerized and it is not new machinery imported from developed countries. Female-Male Employment growth refers to the growth in female to male employment ratios between 1991 and 2000. Female-Male Wage Bill is the growth in female to male wage bill ratios between 1991 and 2000. Female-Male wage is the growth in female to male wage ratios between 1991 and 2000 . The wage is computed as the ratio of Wage Bill to Employment. The growth rate is computed as $\ln (($ female - maleratio $)+0.001)-\ln ((\text { female }- \text { maleratio })+0.001)_{t-1} \cdot \ln (K / V A)_{\text {init }}$ is the $\log$ of total assets to value added in $1991 . \ln (V A)_{\text {init }}$ is value added in 1991. Share $R \& D_{\text {init }}$ is the share of R\&D spending in total income. Foreign $n_{\text {init }}$ is a dummy variable that takes the value of one if the firm was more than 10 percent owned by foreign-owned investors in 1991 and zero otherwise. ${ }^{* *},{ }^{* *},{ }^{*}$, denote significance at $1 \%, 5 \%, 10 \%$ levels. 